\title{
Atlanticism In Visegrad: Understanding the Relationship between Central Europe and the U.S. after 1989
}

Brian S. Valdivia

Follow this and additional works at: https://researchrepository.wvu.edu/etd

\section{Recommended Citation}

Valdivia, Brian S., "Atlanticism In Visegrad: Understanding the Relationship between Central Europe and the U.S. after 1989" (2015). Graduate Theses, Dissertations, and Problem Reports. 6859.

https://researchrepository.wvu.edu/etd/6859

This Thesis is protected by copyright and/or related rights. It has been brought to you by the The Research Repository @ WVU with permission from the rights-holder(s). You are free to use this Thesis in any way that is permitted by the copyright and related rights legislation that applies to your use. For other uses you must obtain permission from the rights-holder(s) directly, unless additional rights are indicated by a Creative Commons license in the record and/ or on the work itself. This Thesis has been accepted for inclusion in WVU Graduate Theses, Dissertations, and Problem Reports collection by an authorized administrator of The Research Repository @ WVU. For more information, please contact researchrepository@mail.wvu.edu. 


\title{
Atlanticism In Visegrad: Understanding the Relationship between Central Europe and the U.S. after 1989
}

\author{
Brian S. Valdivia
}

Thesis submitted to the Eberly College of Arts and Sciences at West Virginia University

in partial fulfillment of the requirements for the degree of

Master of Arts in History

Robert Blobaum, Ph.D., Chair

Joseph Hodge, Ph.D.

James Seikmeier, Ph.D.

Department of History

Morgantown, West Virginia

2013

Keywords: Atlanticism, Visegrad Group, V4, Central Europe, Post-Communism, Foreign Policy, International Relations, Clinton Administration.

Copyright 2015 Brian S. Valdivia 


\section{Abstract \\ Atlanticism In Visegrad: Understanding the Relationship between Central Europe and the U.S. after 1989}

\section{Brian S. Valdivia}

This thesis seeks to explore the relationship of the countries of Poland, Hungary, the Czech Republic, and Slovakia (together known as the Visegrad Group or Visegrad 4 [V4]) with the US after the fall of communism, and how this relationship helped them to transform their political and economic systems. This study will primarily focus on the years between1989-2000, as this was the period during which US-V4 relations were at their peak. After the conclusion of the Clinton presidency, US foreign policy refocused its priorities as the US saw Central Europe as finally part of the Atlantic world and therefore able to handle its affairs on its own. This close relationship between these Central European countries and the US can be defined in terms of Atlanticism, the idea that both Europe and North America prosper when working together to build stronger political and economic ties; a relationship which in many ways was integral to the success of the countries in the Visegrad group as it was earlier for Western Europe under the Marshall Plan. In this thesis, I argue that it is this relationship based on Atlanticism, in combination with the united regional front that these countries presented in coordinating their foreign policy approaches in the last decade of the twentieth century, which enabled them to successfully integrate into the economic and political structures of Europe, and in a broader sense, the Atlantic world. 


\section{Table of Contents}

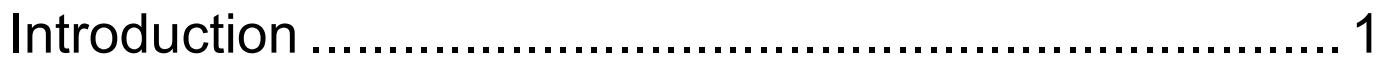

A Rock Solid Commitment ......................................................

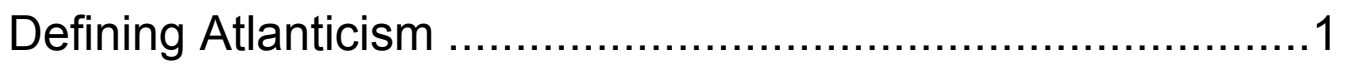

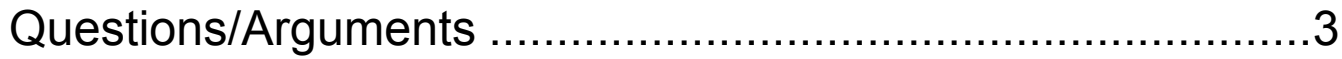

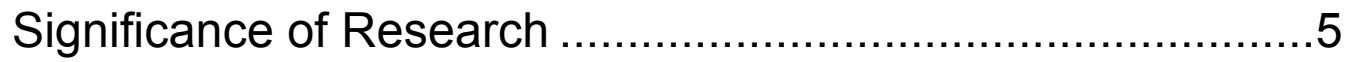

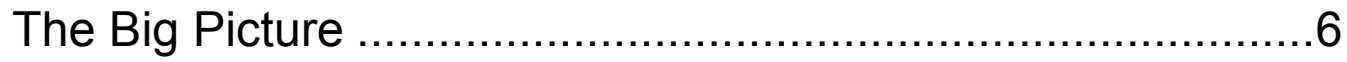

Chapter 1: A History of Visegrad ............................. 10

Before the Fall: Cooperation Begins ....................................10

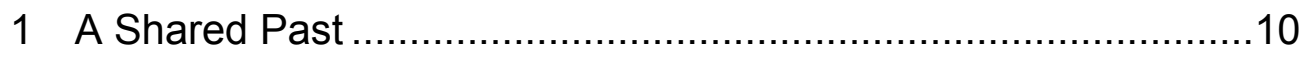

2 Opposition to Communism ..........................................................

3 The Revolutions ........................................................................

After the Fall: Building Up Visegrad ..................................19

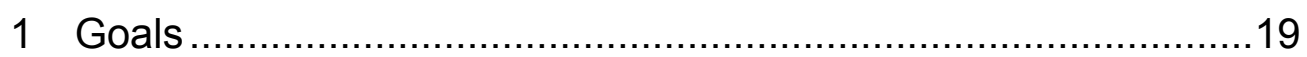

2 Domestic and Regional Policies ...................................................22

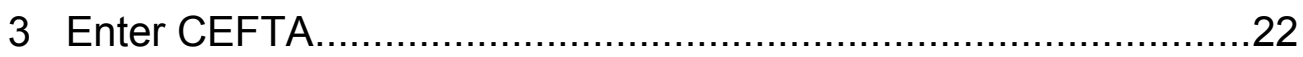

4 Looking to the West (Developing a Foreign Policy) …….............25

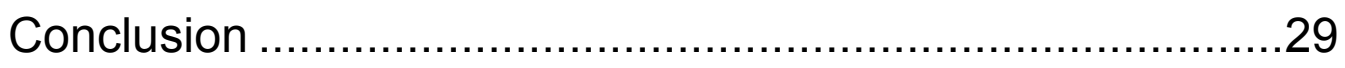

Chapter 2: The Transition Process ............................ 32

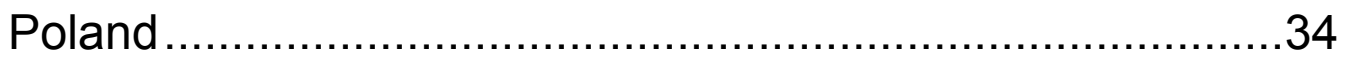

1 Political Transition …………………………………………..........

2 Economic Developments/Struggles .............................................39 


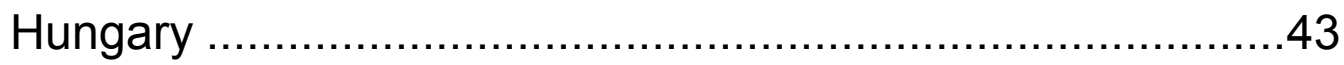

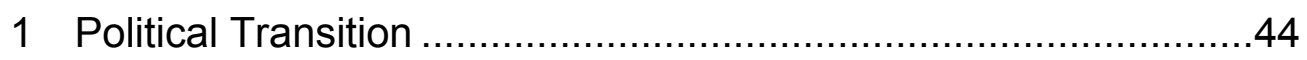

2 Economic Developments/Struggles .........................................48

Czechoslovakia .............................................................50

1 Before the "Velvet Divorce" ....................................................51

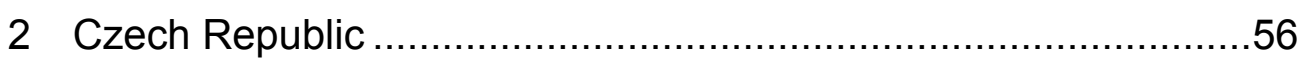

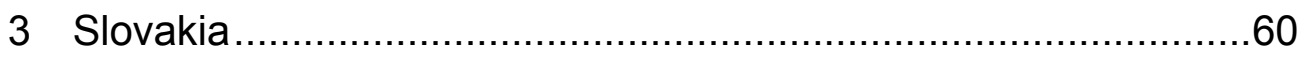

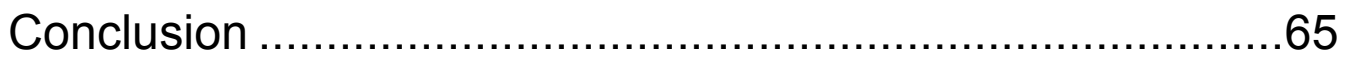

Chapter 3: The Clinton Administration ........................67

Atlanticism before Clinton .............................................67

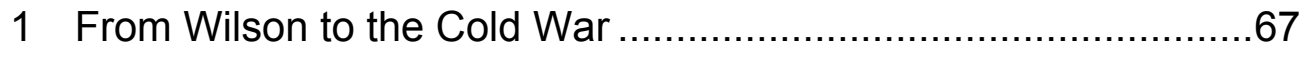

2 The Carter Administration ........................................................

3 The Reagan Administration .................................................. 74

4 The Bush Administration .......................................................

Clinton and Visegrad ................................................. 79

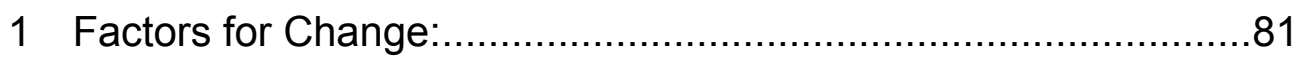

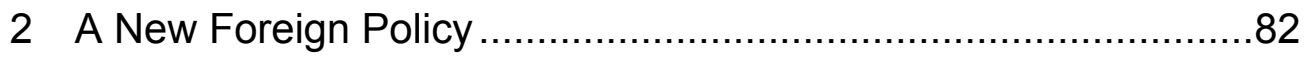

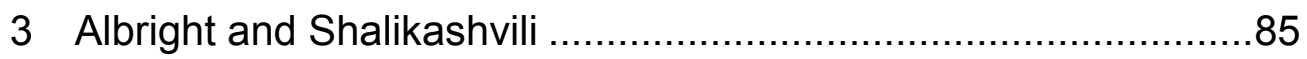

4 Selling the Partnership for Peace ............................................. 88

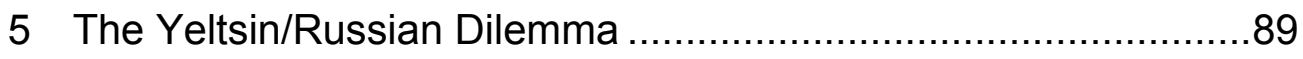

The Yugoslav Wars....................................................... 91

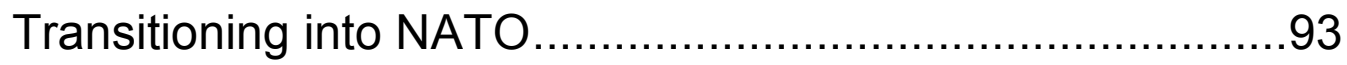

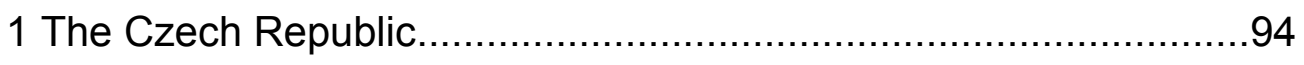

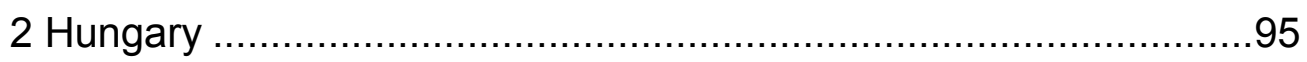




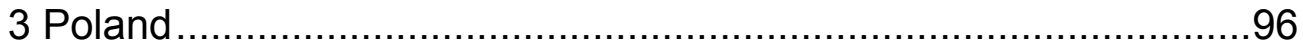

Conclusion ..................................................................

Ch. 4: Results and Conclusion................................ 101

Foreign Investments and the EU ...............................101

Visegrad Refocused....................................................104

Redefining Atlanticism ............................................. 108

Conclusion ............................................................... 110

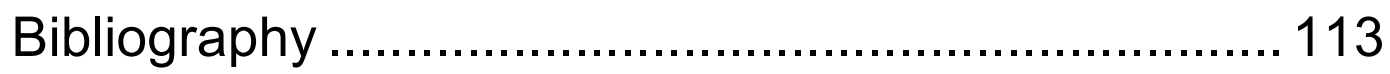




\section{Introduction}

\section{A Rock Solid Commitment}

On June 3, 2014, United States President, Barack Obama, delivered a speech in Warsaw, Poland to unveil his $\$ 1$ billion security plan for Central Europe. ${ }^{1}$ Because of the 2014 crisis in Crimea, President Obama felt it necessary to remind Central Europe that the US has a "rock solid commitment" in making sure that the countries in this region are protected from Russian aggression. ${ }^{2}$ However, in order to understand exactly why the US feels this "rock solid commitment" to Central Europe, we must look back to 1989 after the fall of communism.

\section{Defining Atlanticism}

This thesis seeks to explore the relationship of the countries of Poland, Hungary, the Czech Republic, and Slovakia (together known as the Visegrad Group or Visegrad 4 [V4]) with the US after the fall of communism, and how this relationship has helped them to transform their political and economic systems. This study will primarily focus on the years between 1989-2000, as this was the period during which US-V4 relations were at their peak. After the conclusion of the Clinton presidency, US foreign policy refocused its priorities as the US saw Central Europe as finally part of the Atlantic world and therefore able to handle its affairs on its own. This close relationship between these Central European countries and the US can be defined in terms of Atlanticism, the idea that both

${ }^{1}$ Peter Baker and Rick Lyman, "Obama, in Poland, Renews Commitment to Security," The New York Times, June 03, 2014.

${ }^{2}$ Ibid. 
Europe and North America prosper when working together to build stronger political and economic ties; a relationship which in many ways has been integral to the success of the countries in the Visegrad group as it was earlier for Western Europe under the Marshall Plan.

In this thesis, I argue that it is this relationship based on Atlanticism, in combination with the united regional front that these countries presented in coordinating their foreign policy approaches in the last decade of the twentieth century, which enabled them to successfully integrate into the economic and political structures of Europe, and in a broader sense, the Atlantic world. For the Visegrad group, this success has meant that despite a rocky transition and ongoing concerns regarding economic growth and rising debt, three out of these four states, Poland, Czech Republic and Slovakia, have joined the ranks of the US and the UK as high-income countries as defined by the world bank. ${ }^{3}$ All four countries score highly on United Nation's Human Development Index (HDI), which indicates the potential for human development if there were no inequality, and on the Inequality-Adjusted Human Development Index (IHDI), the actual measure of human development when taking inequality in society into account. In fact, currently, the Czech Republic, Slovakia, and Hungary all outrank the US in this regard, with Poland following just behind. ${ }^{4}$

3 "Country and Lending Groups," Country and Lending Groups, N.p., n.d. Web. 08 Apr. 2015, http://data.worldbank.org/about/country-and-lendinggroups\#High income. 4 "Sustaining Human Progress: Reducing Vulnerabilities and Building Resilience," Human Development Report 2014 26,1 (2014) Web, 8 Apr. 2015, http://hdr.undp.org/sites/default/files/hdr14-report-en-1.pdf. 


\section{Questions/Arguments}

In order to fully understand the relationships within and the development of the Visegrad Group, one must first understand the differences in their paths and trajectories, both before and after 1989. Therefore, we will start by examining the different circumstances under which each of the Visegrad countries integrated into the Atlantic world. In exploring which of these countries made the fastest and least difficult transition, which countries experienced greater growing pains, and identifying some of the reasons behind these smooth, or rocky, integrations, we may be better able to understand the political and economic trajectories of these countries, and their position in the wider economic and political picture of Europe today.

Finally, we will need a thorough understanding of US involvement in the economic and political development of the Visegrad Group. We will start by analyzing the Clinton Administration's attitudes, goals, and policies enacted during the 1990's. Specifically we will analyze what is known as the Partnership for Peace (PFP) policy, which was Clinton's way of initially bringing Poland, Hungary and the Czech Republic into the Atlantic World. As we will see, due to certain circumstances, Slovakia would have a much tougher time breaking into the Atlantic World. Furthermore, to better understand the history behind the relationship between the Visegrad group and the US, we will explore such questions as "Why did Central European countries seek to 'Return to Europe' after 1989?", "What were the main characteristics of their post-communist policies that helped them integrate into Western institutions?", "How did the US 
help bring the V4 into Western institutions?", "What did the U.S. receive from this relationship?", "What is the relationship of the V4 to the US today?" and finally "What was, and continues to be the role of Atlanticism in this relationship?".

It is also imperative that we consider the role and relationship between countries of the V4 today given the authoritarian turn in Hungary and the rise of powerful right-wing movements in the other countries of the region. Therefore, I have dedicated a section in the concluding chapter to briefly discuss the relationships among the V4 today, given the impact of rising nationalism on the current political climate in the region. Before diving into this thesis, we understand that Visegrad should not be seen as an organization that is always in agreement about all issues. Rather as Senior Fellow at the Finnish Institute of International Affairs, Andras Racz puts it, "Visegrad was never intended to settle intra-Visegrad debates... Visegrad is intended, and will remain so, to promote those interests in common," most recently in response to the 2015 Syrian refugee crisis. ${ }^{5}$ By answering the above questions, we will have a better understanding of how the US helped the V4 enter into the Atlantic world through such acts as joining the North Atlantic Treaty Organization (NATO) and the European Union (EU), why the US still feels a commitment to this part of the world, and what the V4 means today in Central Europe.

\footnotetext{
${ }^{5}$ Wojiech Przybylski, "Visegrad Differences will always exist: But the V4 is Much Stronger Than Critics Make Out", Visegrad Insight, Res Publica Foundation, 26 Sep. 2014, http://visegradinsight.eu/visegard-differences-will-alwaysexist26092014/.
} 


\section{Significance of Research}

What is important to note is that while there is significant information on the relationship between the Visegrad countries and the US, few scholars have discussed the specific policies pursued by both sides during the years 1989 through 2000, the peak of US-V4 relations. Political analysts Ronald D. Asmus and Alexandr Vondra have discussed the history of the relationship between Visegrad and the US, but fail to be precise when addressing the significance of the relationship between the US and V4. ${ }^{6}$ When visiting the Visegrad Group's main website one will notice that the organization tends to downplay the support it received from the US and does not list any of the policies taken by the US in order to aid the V4. Polish diplomat Andrzej Ananicz goes so far as to say that the US and the Clinton Administration with its Partnership for Peace policy were in fact initially trying to hinder the development of the Visegrad by only offering partial integration into NATO. ${ }^{7}$ To respond to this kind of critique, we must explore more closely the policies of the Clinton presidency, as it was the Clinton administration that answered the plea of the Visegrad countries for economic and political support from the Atlantic world after the fall of Communism.

From the perspectives of Asmus and Vondra, it would seem that the Visegrad countries' futures may rely heavily on their relationship with the U.S. However, with relatively high unemployment rates, an aging work force, the

${ }^{6}$ Ronald D. Asmus and Alexandr Vondra, "The Origins of Atlanticism in Central and Eastern Europe," Cambridge Review of International Affairs 18 no. 2 (2005): 203-16.

${ }^{7}$ Andrzej Ananicz, "From the Anti-Communist Underground to NATO and the EU," International Visegrad Fund, http://www.visegradgroup.eu/the-visegradbook/ananicz-andrzej-from-the. 
inability to keep young people in country, and in the case of Hungary, an economy in recession even before the 2008 financial crisis, perhaps the Visegrad countries should look inward to reform their economies whose difficulties have already had social and political impacts. However, looking outward has led them to some degree of success in the past; by forming the Visegrad group and pursuing a policy of strong Atlanticism, not only did Central European countries seek to ensure each state's security, but they also began a process of forming a strong regional bloc of states with common interests to become an increasingly powerful voice in the European sphere. In examining the development of the Visegrad Group in Central Europe and its involvement in NATO and the EU, it becomes clear that in helping one another during the transition process through economic and political cooperation and allying with the West, these states were able to rise from the ruins of Soviet-bloc communist systems to become the independent EU member states that we know today.

\section{The Big Picture}

This discussion has become increasingly relevant in light of the 2014 Crimean and Ukrainian crises; Atlanticism has once again taken center stage, as old fears about Russia have once again re-emerged. US President Barack Obama's security plan for Central Europe will include expanding "military training, joint exercises and troop rotations while pre-positioning equipment in the region to bolster defenses for American allies." ${ }^{8}$ However, Polish and other Central

\footnotetext{
${ }^{8}$ Baker and Lyman, "Obama, in Poland, Renews Commitment to Security,"
} 
European politicians have doubts about how serious President Obama is about committing not only money, but also troops in Central and Eastern Europe. ${ }^{9}$ This might have to do with the realization that the US Government, as well as the American public, is apprehensive about sending troops abroad after the wars in Iraq and Afghanistan. Additionally, the amount of resources a president can offer a country without the support or approval of Congress is often the subject of domestic political contestation. In a time where bi-partisanship seems to be at an all time low in American politics, it will be difficult for the Obama administration to convince both Republicans and Democrats to agree on the situation in Crimea and Central/Eastern Europe. On top of all this we must also wonder how Hungarian Prime Minister, Viktor Orbán's close relationship with Russian President Vladimir Putin will affect this situation. Also with the newly elected 2015 Government in Poland, who is leaning towards strengthening relations with Russia, we must also wonder if Poland will even want the security plan offered by President Obama and the US. Other questions such as how much money, how many advisors and how many troops the US will send will surely be heavily debated within Congress. Only time will tell how much of Obama's plan will be implemented and whether it can be considered a success.

With prompting from the Baltic States and former Polish government, the US has also placed economic sanctions on Russia in order to remind its political leadership that its actions in neighboring states will not go unanswered. This is yet another example of Atlanticism at its best, specifically in light of the

${ }^{9}$ Ibid. 
reluctance of a number of European countries, including France, Germany and even Hungary and Slovakia, to put their economic relationships with Russia at too much risk. ${ }^{10}$ At this time, many European countries are heavily dependent on Russian oil and natural gas, and therefore in no position to take any severe measures that would hurt relations with Russia. ${ }^{11}$ Because of this energy dependency, it will be up to the US to foster a stronger relationship with the V4 countries, as well as the rest of the EU, in order to help deter future aggression which would be in the interests of both the US and Central/Eastern Europe. However, as we will discuss in the concluding chapter, two major problems facing the V4 include coming to an agreement on how to handle relations with Russia, as both Hungary and Slovakia are heavily dependent on Russian energy. Secondly the V4 are currently struggling with how to handle the situation occurring in Ukraine as it is a lesser concern for the Czech Republic and seen more as a Polish problem. While development of the relationship between the US and the Visegrad countries has been affected by current uncertainty of US economic and military aid, it is clear that the strategy of Atlanticism, from the US side, is still hard at work in addressing the security concerns of the V4. These events have only proved the need for a continuing commitment to this part of the world, and ensuring the preservation of their democratic political systems and national sovereignty. The next chapter will begin with a brief history of the Visegrad Four so as to better understand how these four counties came to be

\footnotetext{
${ }^{10}$ Frank Dohmen, "Cold Turkey: How Germany Could End Russian Gas Dependency," Spiegel Online, Spiegel Online 2014, 06 May 2014.

${ }^{11}$ German Lopez, "This Map Shows Europe's Dependence on Russian Gas," Vox, Vox Media, 25, July 2014.
} 
united under one cause, the pursuit of regional economic development and political security. 


\section{Chapter 1: A History of Visegrad}

Cooperation between future representatives of the $\mathrm{V} 4$ began long before the revolutions of 1989. Historical and cultural ties to each other, as well as to the West, have bound the histories of Poles, Hungarians, Czechs and Slovaks for centuries. However it should be noted that years of conflict and animosity have also defined relationships in the region. As recently as 1968, troops from Poland and Hungary participated in the Warsaw Pact invasion of Czechoslovakia. Nonetheless, friendly ties were strengthened in the 1970's and 80's during a period of dissent and revolution within Central Europe. With an understanding of each country's history before the collapse of the Soviet Union, we will discuss and analyze the development of the Visegrad group in the early 1990's. Lastly by looking at the goals, domestic and regional policies, as well as attitudes toward the West displayed by the Visegrad group it will become clear the initial importance of the V4.

\section{Before the Fall: Cooperation Begins}

\section{A Shared Past}

In Central Europe: Enemies Neighbors, Friends, author Lonnie R. Johnson shows us that the ties between the V4 countries stem as far back as the Middle Ages. Specifically Johnson shows us that what originally bound these peoples together was their indoctrination into Roman Catholicism which was brought by Western Missionaries in the early Middle Ages. ${ }^{12}$ We come to see that

${ }^{12}$ Lonnie R. Johnson, Central Europe: Enemies, Neighbors, Friends, (Oxford, ENG: Oxford UP, 1996), 3. 
because of Roman Catholicism, Central Europe sees itself as a longstanding historical representative of Western European culture. This also has to due with the fact that Central Europe would become the frontier of Western Culture in the sense that their eastern borders would be where Roman Catholic influence ended, and where Eastern Orthodox influence began. ${ }^{13}$ These borders, which were established by the Holy Roman Empire around 1500, would help cement Central Europe as part of the Western sphere for centuries to come. But it wasn't just religion and culture that tied these peoples together.

In both Johnson's Central Europe and Padraic Kenney's A Carnival of Revolution, the authors discuss that Central Europe, specifically the area encompassing postwar Poland, Hungary, and Czechoslovakia have a common past in east-central European dynasties as part of the Hapsburg Empire. ${ }^{14}$ The families that would ascend to power in the late $9^{\text {th }}$ and early $10^{\text {th }}$ centuries included the Arpad dynasty of the Kingdom of Hungary (which also included present day Slovakia), the Premysl Dynasty of the Bohemian Massif, and the Piast dynasty of the Kingdom of Poland. ${ }^{15}$ What tied these areas and families together were two aspects, problems and solutions. All three dynasties faced the problem of maintaining power and land within and outside their kingdoms. To combat these issues the dynasties had to engage with one another in bloody wars, friendly alliances and marriage pacts in order to maintain power. ${ }^{16}$ From

${ }^{13}$ Ibid, 4.

${ }^{14}$ Padraic Kenney, A Carnival of Revolution: Central Europe 1989, (Princeton, NJ: Princeton UP, 2002) 3-4.

15 Johnson, 32.

${ }^{16}$ Ibid, 32. 
these interactions with one another these dynastic states also have a shared history of multinational populations. From Johnson, we see that these medieval states "housed a variety of people," due to the constant boarder shifts over centuries of interaction with one another. ${ }^{17}$ To Kenney, it is these shared histories in the Hapsburg Empire that originally brought the $\mathrm{V} 4$ together and even to this day still plays a major role in their cultural ties and diplomatic relationships with one another. ${ }^{18}$ As to the question, why did the V4 seek to "Return to Europe", we can see from both Johnson and Kenney that because of Catholicism, a shared history of dynastic wars, alliances and marriages, as well as imperial domination the V4 countries are fundamentally integrated into European history and culture. With regard to the actual formation and buildup of the Visegrad group, we must turn our attention to a period in the 1970's when dissent against communism first united groups of Central Europeans.

\section{Opposition to Communism}

For Polish diplomat Andrzej Ananicz, cooperation between the Visegrad Four against Communism can be traced back to the 1970's with the dissemination of anti-regime publications and news ${ }^{19}$ He provides examples of organizations that partook in such clandestine activities, including the Workers Defense Committee (KOR), a Polish civil society group that would later inspire the future Solidarity movement in Poland, as well as the Individual Publishing

17 Ibid, 41.

${ }_{10}^{18}$ Kenney, A Carnival of Revolution, 3.

${ }^{19}$ Andrzej Ananicz, "From the Anti-Communist Underground to NATO and the EU," International Visegrad Fund, http://www.visegradgroup.eu/the-visegradbook/ananicz-andrzej-from-the. 
House (NOWA), the first underground publishing house in the People's Republic of Poland in $1977 .{ }^{20}$ Both of these organizations featured activists who were committed to bringing change to Central Europe. Often, activists from Poland, Hungary, and Czechoslovakia would visit one another during the 1970's and 80's in order to spread ideas and information that the ruling regimes would have deemed unfit. ${ }^{21}$ Other forms of early cooperation can be seen in examples of Polish printers and illegal radio transmitter specialists training colleagues in both Czechoslovakia and Hungary. ${ }^{22}$ Such activities are especially important to note because some of these activists, including future Czech President Vaclav Havel ${ }^{23}$ and future Polish Labor Minister Jacek Kuron ${ }^{24}$, would later become the democratically elected authorities in the Visegrad countries once the communist regimes collapsed. ${ }^{25}$ Before we discuss the beginnings of consolidation among

${ }^{20} \mathrm{lbid}$.

${ }^{21}$ Ibid.

22 Ibid.

${ }^{23}$ Vaclav Havel was a leading figure in the dissident movement against the Communist Regime of Czechoslovakia. Specifically he was the dominant leader during the Prague street demonstrations in 1989 and would help negotiate the peaceful transfer of power from the Communists to the people of Czechoslovakia that became known as the Velvet Revolution. Dan Bilefsky and Jane Perlez, "Vaclav Havel, Former Czech President, Dies at 75," The New York Times, 18 Dec. 2011.

${ }^{24}$ Known as the "godfather of a resistance," Jacek Kuron was the senior organizer for the Committee to Assist Workers (KOR), which was the first organization to mobilize striking workers in Poland in 1976. This organization attracted intellectuals, students and cultural figures that would go on to provide support and resources to industrial workers, miners and farmers who were then trying to build an independent labor federation. Michael T. Kaufman, "Jacek Kuron, of Solidarity, Dies at 70," The New York Times, 17 June 2004.

${ }^{25}$ Andrzej Ananicz, "From the Anti-Communist Underground to NATO and the EU". 
the Visegrad countries, we should first examine the revolutions that occurred in the late 1980's that helped bring down Communism in Soviet bloc.

\section{The Revolutions}

After the 1970's and into the 1980's, communism in Central Europe began to weaken rapidly. Long-standing internal issues including political instability stemming from widespread corruption, economic scarcity, and environmental degradation were just some of the major systemic problems that occurred as a result of the actions of the communist regime ${ }^{26}$ Perhaps one of main causes for the collapse of the hegemonic power in the region, the Soviet Union, was the eventual impact of the widespread dissent then fermenting all throughout Central Europe. Padraic Kenney refers to this period as the "Carnival of Revolution," a period of widespread non-violent opposition that was one of the contributing factors to ending communism in Central Europe. Specifically, he refers to the "Carnival" as the three and a half year span that began with the post-Chernobyl demonstrations in Poland in the Spring of 1986 and ended with the Velvet Revolution in Czechoslovakia in November of $1989 .{ }^{27}$ However, it is important to note that opinion regarding the point of origin as well as the means of how the revolution was carried out varies.

In contrast to Kenney, historians Timothy Garton Ash and Gale Stokes view the origins and means of the revolutions somewhat differently. For Garton Ash the events that occurred in Central Europe in '89, which he calls the

${ }^{26}$ Minton F. Goldman, Revolution and Change in Central and Eastern Europe: Political Economic, and Social Challenges (Armonk, NY: M.E. Sharpe, 1997), 3. ${ }^{27}$ Kenney, A Carnival of Revolution 3. 
"refolutions" of ' 89 , begin at different times for Poland, Hungary and Czechoslovakia. In The Magic Lantern, Garton Ash explains that what occurred in Central Europe in 1989 was not a revolution in traditional terms but more of a "mixture of reform and revolution," hence the name "refolution., ${ }^{28}$ One of his most famous quotes illustrates just how different these revolutions really were: "In Poland, it took ten years, in Hungary ten months, in East Germany ten weeks: Perhaps in Czechoslovakia it will take ten days!"29 Throughout The Magic Lantern, the author argues that a combination of popular pressure from below, i.e. opposition movements, as well as "a strong and essential element of change from above led by an enlightened minority in the still ruling communist parties," resulted in roundtable discussions that would lead to the end of communist rule. ${ }^{30}$ In Poland we see that Solidarity, a Polish trade Union founded in 1980, was not only a leading force in the roundtable discussions with the Communist Party but also a catalyst in the opposition movement within Poland. While the Communist regime heavily suppressed Solidarity before 1989 , historian Gale Stokes views the early years of Solidarity as imperative to the Polish revolution because the Union "educated a generation of activists and gave almost an entire nation a taste of running its own affairs." ${ }^{31}$ By early 1989 Solidarity was able to set up a

${ }^{28}$ Timothy Garton Ash, The Magic Lantern: The Revolution of '89 Witnessed in Warsaw, Budapest, Berlin, and Prague (New York, NY: Random House, 1990), 14.

${ }^{29} \mathrm{Ibid}, 78$.

${ }^{30}$ Ibid, 14.

${ }^{31}$ Gale Stokes, The Walls Came Tumbling Down: The Collapse of Communism in Eastern Europe (Oxford, ENG: Oxford UP1993), 47. 
roundtable discussion with the Communist Government and negotiate for a semifree election in June the same year, the first of it's kind in decades.

From both Garton Ash and Stokes we also see similar events occurring in Hungary and Czecholslovakia but just with different opposition movements. In Hungary, we see that in May of ' 88 the Hungarian Socialist Workers Party was able to vote in Karoly Grosz as General Secretary. Grosz, a more open-minded individual when it came to free market economics was seen as a progressive compared to his predecessor Janos Kadar. ${ }^{32}$ Under Grosz new clubs and associations such as the Hungarian Democratic Forum, Alliance of Free Democrats and Alliance of Young Democrats would form and go on to spearhead roundtable discussions by early March of ' 89 which would lead to the collapse of Communist rule within Hungary. ${ }^{33}$

In Czechoslovakia the leading opposition movement, known as the Civic Forum, would be led by famous dissident and playwright Vaclav Havel. ${ }^{34}$ The key to the Forum's success resided in its ability to not only unite students and young people for daily rallies in the city of Prague, but also to host daily press conferences and discussions that would be taped and televised. ${ }^{35}$ What is important to note is that unlike Poland and Hungary, whose revolutions took some time, Czechoslovakia was able to complete its revolution in only 24 days.

\footnotetext{
${ }^{32}$ Stokes, 96.

${ }^{33}$ Garton Ash, 56.

${ }^{34}$ Stokes, 154-56.

${ }^{35}$ Garton Ash, 85.
} 
The reason behind this, claims Garton Ash, is that it was the last of the V4 countries to partake in revolution and learned from the other's mistakes. ${ }^{36}$

It seemed that this revolutionary fervor spread like wildfire throughout Central Europe as many in the region saw the collapse of all communist regimes as imminent. No longer would the people of Central Europe live in a statemanaged and over-regulated society. Instead, they began to be heavily influenced by the Western-style individualism that had been taking root for a number of years. ${ }^{37}$ Eventually, revolutionaries and opposition groups accomplished their goal to challenge communist rule by engaging in both campaigns of civil disobedience and protest as well as roundtable discussions headed by opposition groups that capitalized on the unpopularity of the singleparty system. ${ }^{38}$ These revolts were also about moving away from the dominance of the Soviet Union and making a "return" to Europe and sharing in its democratic freedoms. Regardless of their point of origin, Kenney, Garton Ash, and Stokes illustrate that the revolutions were the turning point; the peoples of Central Europe were determined to take back their countries.

What is important to note about these revolutions is that they brought vastly different groups together under one goal, the end of communism. Be they radical environmentalists, hippies, artists, intellectuals, party members, or

\footnotetext{
36 lbid, 127.

37 Asmus and Vondra.

${ }^{38}$ Generally these campaigns, known as "people power," were non-violent in character and played a crucial part in undermining the communist regime. Nonviolent resistance was also key in defeating the attempted putsch in the Soviet Union in August, 1991; Adam Roberts, Civil Resistance in the East European and Soviet Revolutions (Cambridge, MA: Albert Einstein Institution, 1991), 1.
} 
pacifists, ${ }^{39}$ people from all walks of life were for once largely in agreement. This is what made these revolutions so different from previous challenges to communism, such as the Hungarian Revolution in 1956 and the Prague Spring in 1968; a wide variety of groups joined in voicing their dissent. In contrast, the 1956 Hungarian Revolution was only able to attract the interest of intellectuals, students, and workers but was unable to attract party members, farmers, etc. ${ }^{40}$ Yet by the late 1980's, citizens all across Central Europe from every social group were ready for a new way of life. That being said, it is also important to note that with all of these different types of social movements and personalities, varying types of ideologies also emerged, including anarchism, nationalism, liberalism, and conservatism. ${ }^{41}$ Yet in the midst of debate around how best to go about forming new governments in which all of these groups would have a voice, this much was clear, the postwar era of Soviet domination was over, Communism was breathing its dying breath.

By 1989, Communism in Central Europe had run its course, as citizens could not suffer under the systematic failures of the party-state any longer. ${ }^{42}$ People were tired of living with the fear, confusion, and economic constraints that

${ }^{39}$ Ibid, 4.

${ }^{40}$ We also see a similar situation in the Prague Spring in 1968 where only intellectuals, students and party members mobilized. Without support from every social group of society these movements weren't able to gain enough traction to create real change. Instead, the communist regime would overpower these movements and retain political power; Grzegrorz Ekiert, The State against Society: Political Crises and Their Aftermath in East Central Europe (Princeton, NJ: Princeton UP 1996), 4.

${ }^{41}$ Kenney, A Carnival of Revolution, 4.

42 Attila Ágh, "Transition to Democracy in Central Europe: A Comparative View," Journal of Public Policy 11,2 (1990): 133. 
limited a person's freedom and liberty. At the same time Central Europeans were also attracted by the security that Europe and the West could offer in case of the reassertion of Russian power. Yet the securitization of these states would only be achieved only once they became united under a common set of goals.

\section{After the Fall: Building Up Visegrad}

\section{Goals}

After the revolutions of 1989, Poland, Hungary, and Czechoslovakia began to strengthen mutual cooperation and friendship among themselves as newly sovereign states. As early as the summer of 1989 we see cooperation among the V4 as political opposition groups such as Hungarian Democratic Forum and Solidarity Union in Poland began working together in order to strengthen relations among the different countries. ${ }^{43}$ In early 1990 , the leaders of these countries held their first multilateral summit in the town of Visegrad, Hungary to discuss their future plans ${ }^{44}$ The leaders of the Visegrad countries at the time, including Lech Wałęsa of Poland, Vaclav Havel of Czechoslovakia and Mátyás Szürös of Hungary, met in order to discuss how they could all begin creating new foundations and relationships in order to become stronger politically, economically, and culturally. ${ }^{45}$ Their approach to the transition

${ }^{43}$ Csaba G. Kiss, "How did Visegrad Cooperation Begin," Visegrad Insight (1) 2012: 16-17.

${ }^{44}$ Wojiech Przybylski, “Visegrad Time Line," Visegrad Insight (1) 2012: 14-15.

45 "Visegrad Declaration 1991," The Visegrad Group: The Czech Republic, Hungary, Poland and Slovakia, International Visegrad Fund, n.d. Web. 25 May 
revolved around decentralizing power both politically and economically. Their primary objective was to "eliminate the remnants of the communist bloc in Central Europe, overcome historic animosities between Central European countries, successfully accomplish social transformation and join in the European integration process. ${ }^{46}$ Political and social goals included the construction of a parliamentary democracy in each country, creating modern states under the rule of law that respected human rights and freedoms, and preparing to integrate into the European political and security realms. ${ }^{47}$ This also meant guarantees of freedom of press, assembly, and freedom to practice religion without the threat of persecution. ${ }^{48}$

With regard to economic reform, the Visegrad group's first order of business was to transition from Communist command economies to free-market economies based on the principles of capitalism. ${ }^{49}$ Author and historian Minton Goldman claims that the biggest obstacle facing the Visegrad countries was recovering from a system that had greatly hindered economic growth and development. ${ }^{50}$ Some of the basic goals of the transition included privatizing large and state enterprises, ending monopolies (both state and private), and for the first time, accepting unemployment and bankruptcies as part of the free-

2014. http://www.visegradgroup.eu/documents/visegrad-declarations/visegraddeclaration-110412-2.

46 "History of the Visegrad Group," Visegrad Group: the Czech Republic, Hungary, Poland and Slovakia, International Visegrad Fund, n.d. Web. 23 May 2014. http://www.visegradgroup.eu/about/history.

47 "Visegrad Declaration 1991."

48 Ibid.

${ }^{49}$ Goldman, Revolution and Change, 31.

${ }^{50}$ Ibid, 31. 
market system. ${ }^{51}$ During the communist era, it was mandatory for most people to have a job, so insecurity of employment in a capitalist environment was a significant adjustment for many people. Other economic changes included terminating centralized control of planning and pricing, instead allowing prices to be determined mainly by the markets as well as moving from an industrial to a post-industrial economy as a consequence of global economic change..$^{52}$ The final goals of the newly independent Visegrad countries included dismantling bureaucratic planning pyramids, abandoning subsidies to producers and consumers, using fiscal policy to restrict demand, and making currency convertible, lofty goals indeed. While some countries in the Visegrad Group where able to adopt these changes in a smooth and expedient manner, other countries had trouble making the transition, as will be discussed later on in Chapter 2, specifically when comparing Poland and Slovakia. Problems with privatization, deterioration of the health care system, and environmental issues all arose throughout Central Europe during the transition period. Some countries were just better prepared than others to deal with such issues.

In the initial talks among the Visegrad countries, while there was a heavy focus on establishing democracy and bolstering their economies, one of the most important goals became integrating with not just the European community, but also global institutions. ${ }^{53}$ When officially assembled in February of 1991, the

${ }^{51}$ Ibid, 31.

52 Ibid, 31.

${ }^{53}$ Nathaniel Copsey, "Poland an Awkward Partner Redeemed," in The Member States of the European Union, ed. Simon Bulmer and Christian Lequesne, (Oxford: OUP, 2013), 187. 
Visegrad group knew that by working together, they stood a better chance of arguing their cases for being accepted into the European and wider international communities. However, before beginning that discussion, it's important explore the new policies, both domestic and foreign, that the Visegrad countries undertook.

\section{Domestic and Regional Policies}

As stated previously, some of the immediate domestic and economic policies adopted included supporting the free movement of labor and capital based on the principles of free-market capitalism. Central to this goal was a heavy emphasis on creating favorable conditions for "direct cooperation of enterprises and foreign capital investments aimed at improving economic effectiveness. ${ }^{54}$ Another important policy pursued by the Visegrad group included the modernization of the communications infrastructure, not only among the three members, but also with the rest of Europe through development of and improvements to power systems and telecommunication networks. ${ }^{55}$ This created an environment that both provided for and fostered the free flow of information, press, and cultural values. ${ }^{56}$

\section{Enter CEFTA}

To accomplish the above-mentioned goals, The Visegrad group met in February of 1991 to form the Central European Free Trade Agreement (CEFTA) in order to build trade relations between the non-EU countries in Central Europe.

\footnotetext{
${ }^{54}$ Ibid, 188.

55 "Visegrad Declaration 1991."

${ }^{56}$ Ibid.
} 
The purpose behind this agreement was to implement their goals by mobilizing "joint efforts for the integration of participating countries in Western European institutions and, through this, to join European political, economic, security and legal systems and look for opportunities for close economic and political cooperation.. ${ }^{57}$ This agreement also included the consolidation of democracy, the establishment of a free market economy, the establishment of fair conditions of competition for trade among the CEFTA members, and the continuation of building harmonious relations with one another. ${ }^{58}$ Specifically the main objective of CEFTA was and remains the "establishment of a free trade area by gradual liberalization of mutual trade relations and by the removal of tariff and non-tariff barriers to trade during a transitional period." ${ }^{\text {59 }}$ By December 21, 1992, the Central European Free Trade Agreement was signed by all three Visegrad Countries and went into effect on March 1, $1993 .{ }^{60}$ After it was implemented CEFTA became for a time "the most important multilateral agreement on free trade in the region of the Central and Southeastern Europe." ${ }^{161}$ Since 1994, the Prime Ministers of the CEFTA countries have met yearly at summit meetings in order to discuss that year's progress as well as future goals. By doing this,

57 "Historical Background," Summit of the Prime Ministers of CEFTA Countries, CEFTA, 6 Nov. 2003, Web, http://www.cefta2003.gov.si/eng/cefta/history.

58 "Aims, Objectives and Extent," Summit of the Prime Ministers of CEFTA Countries, CEFTA, 6 Nov. 2003, Web. http://www.cefta2003.gov.si/eng/cefta/aims.

59 "About CEFTA," Summit of the Prime Ministers of CEFTA Countries, CEFTA, 6 Nov. 2003, Web, http://www.cefta2003.gov.si/eng/cefta.

${ }^{60}$ Wojiech Przybylski, "Visegrad Time Line."

61 "About CEFTA." 
CEFTA was able to help solidify the relationship among the V4 countries, which made it possible for them strengthen their economic and political systems.

Today the V4 countries are no longer apart of CEFTA as their membership ended when they joined the EU in 2004. Current members of CEFTA include Macedonia, Albania, Bosnia and Herzegovina, Moldova, Montenegro, Serbia and Kosovo. ${ }^{62}$ What is important to understand about this organization is that, even to this day, CEFTA can be seen as a means for European countries which are not in the EU to prepare themselves for association agreements and potential accession. Currently there are eight former members of CEFTA in the EU: the V4 countries, along with Slovenia, Romania, Bulgaria and Croatia. Chapter 2 will take a look at how the V4 countries used CEFTA to implement their new policies.

With a new foreign policy rooted in promoting capitalism and democracy among the members of the Visegrad group, the original three countries looked west for additional outside support in the fields of economic integration and national security. With such a strong united front and such admirable goals, one would think that the Visegrad group would find support from neighboring west European states, however this was simply not the case.

62 "Central European Free Trade Agreement - CEFTA 2006," Central European Free Trade Agreement, CEFTA, http://www.cefta.int. 


\section{Looking to the West (Developing a Foreign Policy)}

\section{Western Europe}

After years of isolation, the Visegrad countries began looking to Western Europe and the United States for closer political, economic, and military ties. One of the main security concerns for Central and Eastern Europe at the time was a revitalized and potentially hostile Soviet Union. ${ }^{63}$ Because of this fear, the Visegrad countries first looked to Western Europe in hopes of finding economic and financial assistance. The Visegrad countries had hoped to receive aid similar to that of the Marshall Plan in Western Europe after WWII to help rebuild their economies. ${ }^{64}$ Leaders within the Visegrad Group argued that in abandoning communist rule, they had done what both Western Europe and the US had wanted, and therefore they believed it was the West's job to help them establish and support sovereign post-communist states. They were not alone in this belief. In fact, one of the greatest supporters these countries of Central Europe had throughout the 1990's was neighboring Germany, which firmly believed that Western Europe should strengthen its ties with these post-communist countries.$^{65}$ Considering Germany's own history with communism in its eastern half, as well as its long tradition of bridging the East with the West, it is certainly not surprising that it had a vested interest in the future of the Visegrad Group.

${ }^{63}$ Padraic Kenney. The Burdens of Freedom: Eastern Europe since 1989 London, UK: Zed Books Ltd, 2006, 136.

${ }^{64}$ Ibid, 19.

${ }^{65}$ Goldman, Revolution and Change, 42. 
France, on the other hand, saw the situation very differently and was vehemently against bringing in the East-Central European states. Leaders in France at the time, including President François Mitterrand, thought that it would be "decades and decades" before the former communist states of Central Europe would be ready to join the European community. ${ }^{66}$ One of France's initial concerns with allowing new members into both the European Community and later the EU, was that it did not want to strengthen Germany's power and influence. Because of close historical and cultural ties, in addition to the shared experience of communism in East Germany (GDR), Germany was in a position to influence the Visegrad countries in a way that could have greatly benefitted it. In response, France made it a priority to stop the integration of the Visegrad group into European community institutions. For instance, in September of 1991, France blocked a European Community plan to allow Central and Eastern European exports into Western Europe ${ }^{67}$ France wanted to ensure that Western European markets would not become flooded with cheaper agricultural products which would compete against those produced by French farmers. France also opposed a package of trade concessions to the Visegrad countries because of it feared the negative impact it would have on French agriculture ${ }^{68}$ However, despite these obstacles posed by France, Western Europe did not completely turn its back on the Visegrad group.

\footnotetext{
${ }^{66}$ Asmus and Vondra, 208.

${ }^{67}$ Goldman, Revolution and Change, 43.

${ }^{68}$ Ibid, 43.
} 


\section{The EU (Initially)}

In early 1993, the new post-Maastricht EU resisted extending an invitation to the Visegrad countries due to several major issues. First, the EU was deeply concerned about the prospect of mass migrations, as affording membership to the Central European states would provide its many new citizens with the opportunity to resettle in Western Europe. ${ }^{69}$ Additionally, just as France had, other EU states also worried that their own economic interests would suffer from increased competition in the industrial sector. Industries such as textiles, coal, and steel would have been greatly affected had the Visegrad countries been permitted to join immediately. ${ }^{70}$ Finally, it is important to note that when new member states are accepted into the EU, all of the institutions within the Union need to be restructured due to the influx of citizens. A few examples of EU restructuring include adapting to the free movement of new EU citizens, providing benefits and jobs for the new youth population, restructuring EU political institutions including the Parliament and Council, and promoting social inclusion and protection for new cultures entering the EU. ${ }^{71}$ That being said, the EU was willing to make some important concessions.

After initially declining to extend membership to the Visegrad countries, the EU did allow Central and Eastern European agricultural and other exports into Western markets. By June of 1993, EU leaders finally extended a formal invitation of membership to Poland, Hungary, and the newly separated states of

\footnotetext{
${ }^{69}$ Kenney, Burdens of Freedom, 19.

${ }_{71}^{70}$ Goldman, Revolution and Change, 43.

${ }^{71}$ Koos Richelle, "Adapting to the change: The EU Approach to Restructuring," Social Agenda, 27, July 2011: 1-28.
} 
the Czech Republic and Slovakia. ${ }^{72}$ However, in order for these countries to join, they were required to meet the three standards of the Copenhagen Criteria, which was easier said than done. In order to meet the three criteria countries were required to have:

"Politically stable institutions guaranteeing Democracy, rule of law, human rights and respect for and protection of minorities; economically, countries must have a functioning market economy and the capacity to cope with EU competition and market forces. In addition, countries must have the ability to take on the obligations of membership, including adherence to the political, economic and monetary aims of the Union." ${ }^{.73}$

In order to meet these criteria, the Visegrad countries would need economic and political aid. With this in mind, the Visegrad group turned its attention even further west toward North America.

\section{The US}

Since the 1970's, the future political leaders of the Visegrad group had been deeply inspired by American individualism, activism, and idealism. Likewise, the US had taken note of the V4's progress in becoming modern democratic states. This shared interest would lead to the fostering of a relationship that was based on Atlanticism; the belief that cooperation between North America and Europe is necessary. ${ }^{74}$ After 1989, the US became strongly favored in Central Europe. As discussed later on in Chapter 3, many citizens appreciated the role the US had played in helping to end Communist rule. Specifically, US policies were a constant outside agitator against the Communist

72 "Countries," EUROPA, European Union.

${ }^{73}$ Xing Hua. "EU Enlargement in the $21^{\text {st }}$ Century: New Stage and Challenges," CIIS.org, China Institute of International Studies, 23 Sept. 2014.

${ }^{74}$ Tim Dunne, "'When the Shooting Starts': Atlanticism in British Security Strategy," International Affairs 80,5 (2004): 893-909. 
regimes "by bringing attention to human rights violations, by restricting trade in strategic and related goods, and by expanding détente with the Soviet Union to improve the international environment." ${ }^{75}$ This, in combination with Central Europe's desire for security, democracy, and economic prosperity led to the beginning stages of Atlanticism in Central Europe. When Central Europe, specifically the Visegrad group, began to come into its own, the US started to champion the integration of its states into the Atlantic world. ${ }^{76}$ The US understood that integration equaled "the natural step next in the consolidation of freedom and peace on the continent." ${ }^{77}$ However, even though the US may have been ready for Central Europe to become a part of the Atlantic world, as discussed earlier, Western Europe was not as easily convinced. By the mid 90's, the Visegrad group and the US decided that instead of trying to get Poland, Hungary, and the newly separated Czech Republic and Slovakia into the EU, it would be more beneficial to enhance Central Europe's security by other means. This discussion will continue on later in Chapter 3 and will show how the US was able to bring the Visegrad countries into the Atlantic world by campaigning for their acceptance into the North Atlantic Treaty Organization (NATO).

\section{Conclusion}

With the understanding that the ties between Poland, Hungary, the Czech Republic, and Slovakia stem back centuries it becomes clear that cooperation

\footnotetext{
${ }^{75}$ Goldman, Revolution and Change, 15.

${ }^{76}$ Asmus and Vondra, 208.

${ }^{77}$ Ibid, 208.
} 
between the leaders of the Visegrad member states did not simply begin after the fall of communism in 1989, but reached back long before to the period of opposition movements in the 1970's. These relationships between the social movements helped lead to the revolutions that would take Central and Eastern Europe by storm in the late 1980 's, and eventually contribute to the fall of Communism. Initially, the Visegrad states set out with one goal in mind, to rid society of the ills and restrictions of communism. With a recovery plan rooted in democracy and free markets, the Visegrad countries strove to be much like their Western neighbors. However, as shown later on in Chapter 2, some of the V4 countries prospered better than others. Slovakia in particular had a difficult transition process related to various political and economic issues. That being said, it will be important to look at the success that Poland, Hungary, and the Czech Republic were able to achieve through their more aggressive reforms. For instance, by 1996 , over $50 \%$ of Poland's gross national product came from the private sector of the economy. ${ }^{78}$ This is not to say that there were no problems in these countries during the transition period. As will be shown, it is no easy task to shift from one kind of economic model, the Communist command economy, to a completely different one defined by the free market. This transition was rife with problems, including unemployment, rapid inflation, and increased cost of living, frightening prospects for peoples accustomed to the tight control and predictability Communism once offered.

${ }^{78}$ Goldman, Revolution and Change, 37. 
After analyzing these countries' transition process, we will finally be able to move into the main subject of this thesis, the relationship between the Visegrad group and the United States after the fall of communism. Chapter 3 will examine the attitudes, goals, and policies pursued by the US, and hopefully shed more light on why, even to this day, the United States maintains a "rock solid" commitment to this area of the world. Finally the results of these policies, including the Visegrad group's acceptance into both NATO and the EU and what that meant at the time will be discussed. Once again, the aim of this research is to not only understand the history of this relationship, but to also ascertain why the US's commitment to both Central and Eastern Europe remains so vital. 


\section{Chapter 2: The Transition Process}

Before they could enter NATO, the EU, and the Atlantic world, the countries of the Visegrad group had to first establish themselves as politically democratic states with economically viable free markets. The primary goal was to demonstrate to the Atlantic world that not only were these countries embracing change, but that they were also committed to dismantling the systems and practices that characterized communism. Once they were able to show significant progress in this direction, the US and the rest of the Atlantic world would be more inclined to offer both political and economic support. However, this was easier said than done.

All three (and later four) countries had difficulties with the transition from communist structures to a new system that focused on the decentralization of power. It is important to note that all of the Visegrad countries had different approaches when it came to ridding their country of the remnants of communism. With regards to economic change, the V4 countries would have to change over from a command-style economy that was greatly centralized to an economy based on free market principles. New reforms that the future V4 countries would have to address included how to handle private property, private capital and capital markets as well as creating a new entrepreneurial class and laws that would govern investment, banking, property taxes and businesses. ${ }^{79}$ On top of this, new institutions would have to be created in order to deal with all of these issues. This would prove to be difficult for some more than others. However, the

${ }^{79}$ Johnson, 288-89. 
biggest problem facing the newly independent countries was privatization or "transferring the ownership and control of assets from the state to the private sector and diversifying ownership." ${ }^{80}$ As will be shown, each country handled their economic transition period very differently. In Poland, for example, the country used a method known as "shock therapy", meaning that economic reforms were instituted immediately and simultaneously. Both Poland and Hungary were able to successfully, and rather quickly, transform its economies and government to mimic those in Western Europe and the US. However, Czechoslovakia had a much harder time transitioning. For the most part, this was because at the time, Czechoslovakia was preparing its "velvet divorce", leading to the establishment of two new Visegrad countries, the Czech Republic and Slovakia. Slovakia in particular had the hardest time during the transition process because of the authoritarian rule of then Prime Minister, Vladimír Mečiar. Mečiar, unlike the other Visegrad leaders, didn't think that economic reforms should be instituted at a rapid pace in the "Big Bang" approach proposed by Czech politician and finance minister Vaclav Klaus. Rather, Slovakia wanted to proceed at a much slower pace, hoping to help curb problems such as unemployment and inflation.

Throughout this chapter similar themes occurred in each country, including the difficulties of economic change, the rise of nationalism, the rise of competing political parties, and issues such as unemployment and inflation. To

${ }^{80} \mathrm{Ibid}, 290$. 
simplify things, I will break up each case study into two parts: political transition and economic development/struggles.

\section{Poland}

\section{Political Transition}

Historian and analyst Minton F. Goldman explains that after the fall of the communist regime, the Poles transformed their government from one that was dominated by the Communist Party to a parliamentary democracy. In the June 1989 Parliamentary elections, the first real, if only partially free elections held within the communist world in many decades, the movement known as Solidarity would go on to win $90 \%$ of the freely contested Senate seats. Although the majority of seats in the lower house, the Sejm, had been reserved for the communists and their allies, Solidarity's clear victory gave it the upper hand in negotiating with the communists. ${ }^{81}$ One month later, Presidential elections were held during which the last leader of the Communist People's Republic of Poland, Wojciech Jaruzelski, was elected by only by a small majority of the Sejm. Once in office, Jaruzelski had to be cautious about using his power because of Solidarity's undisputed electoral victory. ${ }^{82}$ With this in mind, Jaruzelski asked Solidarity to nominate a candidate for the position of Prime Minister. A highranking Solidarity political activist by the name of Tadeusz Mazowiecki was selected to become Poland's first non-communist Prime Minister. ${ }^{83}$

${ }^{81}$ Goldman, Revolution and Change, 224.

82 Jaroslav Kurski, Lech Walesa: Democrat or Dictator? (Boulder, Co: Westview Press, 1993), 79-81.

${ }^{83}$ Kenney, Burdens of Freedom, 103. 
By December of 1989, the Polish parliament had abolished Article 3 of the country's constitution, which reserved for the communists the "leading role" in the state, thereby officially ending their authoritarian rule over Poland. ${ }^{84}$ To celebrate this occasion, the parliament also voted to change the country's name from "Polish People's Republic" to the "Polish Republic." Other amendments to the Constitution included a provision in support of liberal and pluralist political systems, as well as the freedom to create new political parties. ${ }^{85}$ These changes helped initiate the process to decentralize both the government and economy.

Central to the democratization of the Polish political system was restoration of freely contested local elections. Political scientist Emil J. Kirchner explains that in early 1990, the new Polish Government had scheduled local referendums in order to determine how communities would govern themselves. ${ }^{86}$ Essentially, the Poles viewed this new initiative of self-governance as the first steps toward democratization, as the people's opinion and input would finally have a place to be heard, and one of the most important tasks of these new local governments was to set up a tax system that would help fund their communities. This tax system would include property taxes, taxes on transportation means, farmland and forests, and even a stamp duty. ${ }^{87}$ These taxes would go toward local government funding of community services, including fire departments and hospitals. With such success at the local level, one would think that the efforts at

${ }^{84}$ Goldman, Revolution and Change, 226.

${ }^{85} \mathrm{Ibid}$.

${ }^{86}$ Emil Joseph Kirchner. Decentralization and Transition in the Visegrad: Poland, Hungary, the Czech Republic and Slovakia. (New York: St. Martin's 1999), 5354.

${ }^{87}$ Ibid, 57 
transition at the national level would be a success from the start. However, this would not be the case.

\section{Political Problems}

One of the first major problems faced by the Polish people during the transition was the factionalism within the Solidarity movement. It is imperative to understand that what brought the Solidarity movement together was opposition to communism. As mentioned in Chapter 1 , what made the Solidarity movement so successful was that people from all different walks of life came together under one cause. However, once communism ended in Poland, Solidarity no longer had a goal that could unite its constituent parts. ${ }^{88}$ Instead, what occurred was the emergence of competing political parties. The two most influential parties that came out of Solidarity were the Citizens Movement for Democratic Action (ROAD), and the Center Alliance. Heading ROAD was Prime Minister Mazowiecki, who thought that Solidarity should transform itself into a political party with defined goals and policies. ${ }^{89}$ In response to this move, co-founder of the Solidarity movement Lech Wałęsa formed the Center Alliance, which thought that Solidarity should remain an amorphous organization that didn't ostracize anyone. Wałęsa wanted to create a political system that represented all instead of just the majority party. ${ }^{90}$ However, the major difference between the two parties and their leaders was their stance on how the economic reforms should be implemented.

\footnotetext{
${ }^{88}$ Kenney, Burdens of Freedom, 107.

89 Ibid.

${ }^{90} \mathrm{lbid}, 109$.
} 
Defending a rapid transition process that would bring a free-market economy to Poland was Wałęsa and the Center Alliance. Wałęsa was convinced that if Poland was going to make changes, that two things needed to be done. First, an immediate overhaul of the communist command economy needed to be executed in order for Poland to transform into a free-market system. Secondly, Wałęsa wanted to rid the political system of any former Communist politicians that were still in power. ${ }^{91}$ This was directly aimed at President Jaruzelski, who because of rising pressure resigned his position in September of 1990.

On the opposite side of the spectrum were Prime Minister Mazowiecki and ROAD, who supported a more gradual approach to economic reform. The reason for this was that Mazowiecki and his supporters were nervous about the effects that such a transition could have on the people of Poland. Bear in mind that the Polish people, for the most part, had not experienced participatory democracy in decades, meaning that it might take some time to adjust to the new political reality. Additionally, it is worth noting that this generation of Poles had grown-up under the influence of Communism, and a cradle-to-grave social security net that guaranteed work, food, and shelter. This is important to mention because now people could no longer expect the government to aid them in times of need. By November 1990, it was evident that only one of these parties would emerge the victor in the Presidential Election, the first to be decided by popular vote, and on December 9 1990, the people's decision was clear. Lech Wałęsa would become Poland's next president; the country had sided with Wałęsa on how they wanted

${ }^{91}$ George Sanford, Democratization in Poland, 1989-1990: Polish Voices, (New York: St. Martin's Press, 1994), 122-123. 
the transition process to occur. ${ }^{92}$ The next section will discuss Wałęsa's presidency from 1991-1995 as most of his administration's focus was centered on the economy, but for now, but it is imperative to first look at some of the political accomplishments that occurred in the early 90's.

One of the most significant political developments for Poland came in 1992 when politicians from all parties agreed that it was time for a new constitution. The former Constitution was viewed as outdated and obstructive to the new political and economic changes that Wałęsa was trying to accomplish. ${ }^{93}$ With this in mind, on November 17, 1992, the Polish Parliament established what was called the "Little Constitution". In a nutshell, the "Little Constitution" abolished the old 1952 Constitution, made the president responsible for implementing foreign policy and commander-in-chief of the army, and strengthened parliamentary control over the choice and behavior of the Prime Minister and his cabinet, thereby making it harder for a dictatorship to emerge. ${ }^{94}$ By 1997, following a popular referendum organized under a new government, an official constitution was adopted that strengthened Poland's reputation as a parliamentary democracy. Today, this Constitution is the cornerstone of Polish democracy, as it clearly establishes how the government and its branches operate.

92 Kenney, Burdens of Freedom, 35.

${ }^{93}$ Sanford, Democratization in Poland, 234.

${ }^{94}$ Ibid, 235. 


\section{Economic Developments/Struggles}

The roots of Polish economic change began in 1989 when the newly elected government decided to approve a rapid economic reform plan known as the "Balcerowicz plan." ${ }^{.95}$ two-stage strategy was set up that included taking measures to stabilize their currency and stop inflation and rapidly privatizing state-held enterprises. ${ }^{96}$ The first strategy involved opening Poland up to the world economy and making its currency convertible, freeing most government regulated prices, and easing small entrepreneurs into business. ${ }^{97}$ The second strategy of privatizing industry would prove to be more difficult. At the time, the finance minister of Poland, Leszek Balcerowicz suggested that the Polish economy needed "shock therapy" treatment; rapid and radical change. This would essentially be Poland's first steps toward the free market system; however, this is not to say that there were no problems.

One of the first effects of the "shock therapy" transition period was the rise of prices in commodities including electricity, gas, and coal; electricity and gas rose $400 \%$ in price, while the price of coal soared over $600 \%{ }^{98}$ Other issues included unemployment, which reached $25 \%$ by January 1990 , and declining wages led to strikes in both the railroad and agriculture industries. ${ }^{99}$ Add to this the problem of Poland having an ineffective banking system, which increased the risk for disaster for the new reforms.

\footnotetext{
${ }^{95}$ Ash, 43.

${ }^{96}$ Stokes, 194.

97 Ibid.

${ }^{98}$ Goldman, Revolution and Change, 227.

99 Ibid.
} 
One of the most apparent flaws of privatization was that people lacked the capital and loans required to buy state-owned industries. ${ }^{100}$ People simply did not have the money to help transform the economy from command to free market as intended. This was especially troubling as Poland was trying to improve its international image in order to attract new foreign investors. Other issues that concerned investors was the excess of employees at certain industries, the inefficient products sometimes made, and the enormous environmental deficits that state-run industries accrued. ${ }^{101}$ To combat this negative publicity, the Polish government established a Western-style stock market in April of $1991 .^{102}$ It hoped that this would help promote the message that Poland had a capital market and was open for business. To go along with this, the government also set up a modern, privately-owned bank known as Kredyt Bank. Kredyt Bank was founded by a consortium of private and state-owned Polish companies with the goal of being seen as on the cutting edge of electronic banking. ${ }^{103}$ With these improvements to their financial infrastructure in place, Poland was ready to move forward with true economic reform.

Throughout the early 90's, the effects of economic reform were seen and felt all over Poland. These efforts were largely spearheaded by then Prime Minister, Hanna Suchocka. Under Suchocka, Poland made great leaps toward becoming a free-market economy. Some of these achievements included establishing the Polish currency as internationally convertible and raising the

\footnotetext{
100 Stokes 196.

101 Ibid.

102 Goldman, Revolution and Change, 242.

103 Ibid.
} 
wages of Polish citizens. ${ }^{104}$ During Suchocka's time as Prime Minister, Poland also saw substantial growth in the private sector during which, by $1993,50 \%$ of Poland's workforce was employed by private enterprises. ${ }^{105}$ Once the International Monetary Fund (IMF) saw these changes, it agreed to allow Poland to borrow $\$ 700$ million in order to continue its economic reforms. ${ }^{106}$ However, as Suchocka would learn, there were costs for the improvements that were made to the economy.

One of the biggest fallouts of Suchocka's achievements is that the public blamed her policies for the rise in inflation and unemployment. Because of this, in September of 1993, the Polish parliament voted the coalition led by Prime Minister Suchocka, a major supporter of Wałęsa and rapid economic reform, out of office. ${ }^{107}$ Taking her place was Waldemar Pawlak, a staunch adversary of "shock therapy" who wanted to slow down the economic transition process in order to ease some of the difficulties the Polish people were facing. Historian Padraic Kenney calls this change in the process and speed of economic transition "democratic alternation." ${ }^{\text {"108 }}$ Essentially what would occur in both Poland and Hungary was not so much a crackdown or abandonment of economic reform, but rather it would be either slowed down or sped up depending on how the market and society were reacting. With regards to Pawlak's policies, the

104 Ibid, 244.

105 James Bjork, "The Use of Conditionality: Poland and the IMF," in Eastern European Quarterly 29, no. 1 (Spring 1995): 111.

106 Ibid.

${ }^{107}$ Goldman, Revolution and Change, 235.

108 Kenney, Burdens of Freedom, 34. 
economic transition process in combination with a rough relationship with Wałęsa, meant that the year 1994 saw little privatization occur in Poland.

By 1995, the people of Poland had tired of Wałęsa and his policies and elected Aleksander Kwasniewski as the President. Kwasniewski, a member of the post-communist Democratic Left Alliance, was able to capitalize on his popularity with young people as they saw him as the future of Poland. ${ }^{109}$ However, what made Kwasniewski stand out most was his moderate and restrained attitude on the privatization of the Polish economy. Kwasniewski knew that privatization still needed to happen if Poland was ever going to be accepted into the Atlantic world, but he was also aware of the toll it had taken on the Polish people. With this in mind, Kwasniewski pursued a more gradual approach to implementing privatization. One of his first acts as president was to offer Polish citizens ownership of hundreds of former state companies for a mere $\$ 8$ a share. ${ }^{110}$ This was a smart move on the president's part, because while people had wanted to buy companies from the state, they didn't have enough capital to afford them. At the same time, the President worked on improving the image of Poland to international investors in order to bring more money into the country. ${ }^{111}$

By the end of 1995, Poland's economy was in much better condition than it had been in the previous years. The economic growth rate was at $4.5 \%$ in 1995, making Poland a leader in economic transition within the Visegrad group,

109 Ibid, 111.

110 Pawel Swieboda, "In NATO's waiting room," Transistion 2, no. 8 (April 19, 1996): 52-53.

${ }^{111}$ Goldman, Revolution and Change, 239. 
and unemployment had leveled off. ${ }^{112}$ Finally, Western banks agreed to restructure Polish debt from $\$ 14$ billion to $\$ 7.5$ billion, making it much easier for Poland to repay its debt. ${ }^{113}$ This move would also encourage future foreign investment, which also assisted the transition process, even if it came with nationalist alarms of an "invasion" of foreign and especially German capital.

\section{Hungary}

Just like Poland, Hungary also faced problems, including stabilization of its currency, freeing prices from government control, setting up commercial banking, and trying to fight unemployment as the country began to privatize its industries. ${ }^{114}$ However, unlike its regional neighbor Poland, which opted for a fast paced approach when it came to economic reform, Hungarian politicians took a somewhat different path.

After first exploring Hungary's transition from an authoritarian Communist government to a Parliamentary Democracy, the focus will then turn to how the moderate approach to economic reform taken by the new government both hindered and helped Hungary during its period of transition. It will also be important to examine how the collapse of the communist regime helped give birth to a major nationalist movement within Hungary that is still very much alive today. By analyzing this movement, a better understanding will be gained on why Hungary today is once again moving more towards more authoritarian rule under the government led by Viktor Orbán and the FIDESZ-Hungarian Civic Alliance.

112 Ibid, 246.
113 lbid
114 Stokes, 188. 
Finally an examination will be conducted of some of the economic problems that occurred during the transition process, including unemployment and inflation, increasing poverty, a rise in foreign debt, and the overall sluggish pace of reform.

\section{Political Transition}

In 1989, the Hungarian Communist Party began to democratize the country's political system in order to strengthen public support for the Party. However, because Hungarian citizens had wanted democratic freedom for years by this point, they weren't going to settle for such a small taste. Rather, what ended up occurring was the demise of the communist party within Hungary. By October of 1989, reformers within the communist party saw the end coming and realized that it was finally time to give up the party's monopoly on power and move toward a more Western democratic system. ${ }^{115}$ Out of this decision came the replacement of the Communist Party with the new Hungarian Socialist Party. However, the Socialist party, made up largely of former communists, quickly learned that even with a new moderate approach to politics and a reformist attitude, Hungarians were still wary of trusting those who were part of the old system. With that, the Hungarian Socialist Part was swept out of power in parliamentary elections in March of 1990.

The two major parties to emerge from the ' 90 parliamentary elections were the Democratic Forum Party and the Alliance of Free Democrats (SZDSZ) who both promised to reform not only the government but also the economy. The Democratic Forum party would go on to win a plurality of seats within Parliament,

${ }^{115}$ Kenney, Burdens of Freedom, 20-21. 
making it the leading force during the early transition period. ${ }^{116}$ Leading the Democratic Forum was Jozef Antall, who would become the first Prime Minister of the newly democratized Hungary. Antall and his government promised that the economic reforms would not take the form of "shock therapy" as was occurring in Poland, but rather would be implemented slowly and gradually so as to not put pressure on the Hungarian people. ${ }^{117}$ Antall also expressed his desire to decentralize the political system in order to bring power back to the people. Therefore, on January 1, 1990, the Parliament passed the Local Government Act, which would transform the centralized political system under the communists into a "normative decentralized revenue-driven system."118 The Act called upon "every settlement, even the smallest, to set up a municipal government to manage its own affairs. ${ }^{119}$ This would mean that towns, cities, and districts would now all have representative governments giving people more political freedom and choice. However, this is not to say that there were not any problems for Hungary on the road to democratization.

Some of the initial problems that occurred in the political development of Hungary included oligarchical decision-making by the two ruling parties, the Democratic Forum and the SZDSZ. Within their first few months in power, leaders of both the Forum and SZDSZ secretly met to decide on issues of policy without consulting their colleagues with an agenda that included selecting the

${ }^{116}$ Ibid, 103-104.

117 Ibid, 21.

${ }^{118}$ Kirchner, 133.

119 Ibid. 
cabinet as well as the President, Arpad Goncz. ${ }^{120}$ The problem with this topdown approach is that it hampered the development of true participatory democracy and once again, placed power into the hands of the few. The reason behind this secrecy was that the ruling parties sought to circumvent Hungary's labor unions, which in turn led them to implement the Labor Codes in July of 1992. ${ }^{121}$ In a nutshell, the Labor Codes were a way to weaken and decentralize unions by putting workers under the control of employers. From this example it becomes clear that today's proclivity towards authoritarian rule in Hungary has its roots in the political transition of the early 1990's.

Another major issue facing Hungary was voter apathy towards elections and politics in general. For instance, in the 1990 presidential election, only $66 \%$ of the population casted ballots, as many did not feel connected with the parties' candidates. ${ }^{122}$ This was not just a national political problem, but a local one as well. At the time, Hungarians did not take the local elections seriously because most of them had never really participated in truly free elections. Given this unfamiliarity with the new system, in combination with the fact that on the local level, there were over 60 parties running for election in 1990, and one can see why people felt disconnected to politics. ${ }^{123}$ Lack of voter participation meant that only the loudest voices were heard, and for Hungary, this meant the emergence of a nationalist Right which would eventually come to dominate Hungarian politics. Initially, nationalist rhetoric was voiced mainly by members of the new

${ }^{120}$ Kenney, Burdens of Freedom, 20-21.

121 Goldman, Revolution and Change, 197-198.

122 Ibid, 193.

${ }^{123}$ Kenney, Burdens of Freedom, 104. 
political elite, while the average citizen tended to support the Socialists. The Socialist party consisted mainly of former communists who were looking for a way back into politics. They preached that Hungary's future rested in giving the market economy a "human face" that wouldn't strip away the social safety net that many Hungarians had become dependent on over the years. ${ }^{124}$ By 1994 , the people of Hungary had tired of the economic reforms, though moderate in comparison to Poland, which had nonetheless led to a rise in unemployment and inflation. Because of this, the Socialists would go on to win a clear majority over both the Democratic Forum and SZDSZ parties in the May '94 Parliamentary elections. ${ }^{125}$ Because of support from the unemployed and elderly, in combination with the fact that people longed for the stability associated with communist rule, the Socialists were able to sweep the elections and regain power. They remained in power until 1998, when an old rival made a surprising comeback.

\section{FIDESZ- From Liberal to Conservative}

During the ' 90 and '94 Parliamentary elections, a new political party of young liberals entered the political arena. FIDESZ, or the Alliance of Young Democrats, was composed of young moderate liberals who supported programs of modernization and opposed radical nationalism. ${ }^{126}$ Its leader, Victor Orbán, was an avid supporter of rapid privatization and fundamental economic reforms. In the 1990 Parliamentary elections, FIDESZ went onto to receive $8.95 \%$ of the

124 Ibid, 200.

${ }^{125}$ Andrew Michta, "The Presidential Parliamentary System," in The Transition to Democracy in Poland, ed. Starr: 69-70.

${ }^{126}$ Goldman, Revolution and Change, 202. 
vote. ${ }^{127}$ However, because of the growth in popularity of the Socialists, who advocated a slower transition process, FIDESZ only won $7.02 \%$ of the vote in the Parliamentary elections of $1994 .{ }^{128}$ Because of this electoral setback, FIDESZ and Orbán changed their political stance from liberalism to conservatism and, eventually, nationalism. They also changed the party's name from FIDESZAlliance of Young Democrats to FIDESZ-Hungarian Civic Party in $1995 .{ }^{129}$ With this change in ideology came a flood of new members and citizens who identified with the party. This is important to note because by 1998, FIDESZ won parliamentary elections and headed a coalition government. After losing elections to the Socialists in 2002, FIDESZ returned to power in 2006 and won super-majorities in the 2010 and 2014 elections. Chapter 4 will come back to the topic of FIDESZ and Orbán to discuss developments in Hungary after the country joined the EU in 2004.

\section{Economic Developments/Struggles}

Because Hungary decided to take a more gradual approach toward economic reforms than Poland had, the country experienced different problems while moving toward a free market. The main issues Hungary faced in 1990 included recession, high poverty levels, a high annual inflation rate of $23 \%$, and

${ }^{127}$ Elisabeth Bakke, "Central and East European Party Systems since 1989," Central and Southeast European Politics since 1989 (London: Cambridge Press 2009): 79.

https://books.google. de/books?id=oFXdiS25N78C\&pg=PA79\&dq=fidesz+nationa I+conservative\&hl=de\&ei=55XGTuj7FZDNswaJ6bDtBg\&sa=X\&oi=book_result\&ct $=$ resul $\mathrm{t} \# \mathrm{v}=$ onepage $\& \mathrm{q}=$ fides $\mathrm{z} \% 20$ national $\% 20$ conservative $\& \mathrm{f}=$ false

${ }^{128}$ Ibid.

129 Ibid. 
the highest per-capita debt in Central and Eastern Europe. ${ }^{130}$ However, it is important to note that Hungary's economic reforms also had an upside. Hungary was one of the first countries of the former Communist Bloc to begin making economic reforms, starting already in the communist era, putting it ahead of other countries such as Czechoslovakia. Hungary was also in the fortunate position of being a member to both the IMF and World Bank, which the country had joined in 1982. ${ }^{131}$ Also in early 1990 when Jozef Antall's government had taken over, private owned small businesses (under 500 employees) were immediately allowed to operate and the state began to levy income taxes. ${ }^{132}$ Finally, Hungary was in a good position in terms of paying back its foreign debt, as Prime Minister Antall made it one of the cornerstones of his policy in order to bring more foreign investment to Hungary. By 1991 10\% of Hungarian firms had a joint venture agreement with some form of foreign investment. ${ }^{133}$ However, there were other economic issues that stalled Hungary's economic reforms.

One of the greatest obstacles that Hungary faced in privatizing its economy was a lack of financial infrastructure. Just like Poland, Hungary lacked the independent banking system required to provide credit to would-be private entrepreneurs. ${ }^{134}$ To combat this, the Hungarian Parliament reformed the legal system in order to support private industries, which laid the groundwork for future independent banks. Once the banking system was established by the mid 90's,

${ }^{130}$ Goldman, Revolution and Change, 204.

${ }^{131}$ Stokes, 201.

132 Ibid.

133 Ibid.

${ }^{134}$ Lucja Swiatowski Cannon, "Privatization Strategy and Its Political Context," in The Transition to Democracy in Poland: 138. 
the government then focused on establishing a stock market. ${ }^{135}$ However, it would not be until the end of the 90's that the Hungarian stock market really took off under the first Orbán government. With unemployment at 8\% in 1991 and growing, most of the early and mid 90's was spent on getting people back to work in order to avoid political destabilization. ${ }^{136}$ Once again, like the rest of the states of the former Soviet Bloc, Hungary was a country that had for years been supported by a social safety net that guaranteed people work and cradle-to-grave social benefits. This social safety net was popular, but in a system based on free markets and capitalism, it became largely unsustainable in the state socialist forms that characterized communism. Politicians had to tread lightly when making difficult, but necessary reforms to these systems. However, there was some progress made as a consequence of the limited economic reforms; soon, half of the GDP was coming from private companies, there was an increase of exports being sold to Western markets, and the break-up of state monopolies and large industrial conglomerates led to more people owning smaller-sized firms. ${ }^{137}$ With this understanding of Hungary's transition period, we can finally turn our attention to the last Visegrad countries, the Czech Republic and Slovakia.

\section{Czechoslovakia}

To understand how the countries of Slovakia and the Czech Republic established their present-day democracies and free market systems, it is crucial

\footnotetext{
${ }^{135}$ Ibid.

136 Ibid.

137 Stokes, 201.
} 
to look back to 1989 when the two states still constituted federal Czechoslovakia. It is important to note that the process of democratization and economic reforms began right after the fall of communism and before what is known as the "Velvet Divorce", or the split of the Czech Republic and Slovakia. Because of this split, the Czech Republic and Slovakia would have very different experiences in their transition process than both Poland and Hungary. Slovakia in particular had a much harder time during its transition period. Just as before, a break down of the political and economic transitions that occurred in both states will be provided so as to better understand why these countries separated as well as how the Czech Republic and Slovakia were able to enter into the Atlantic world. However, before diving into these topics, first an examination of the initial steps taken by Czechoslovakia toward political democratization and free markets will be discussed.

\section{Before the "Velvet Divorce"}

In June of 1989, Vaclav Havel and other leading dissidents in Czechoslovakia had signed the "Just a few sentences" document, which called for the democratization of the Czechoslovakian government. ${ }^{138}$ By November, Havel had created a new democratic political movement called the Civic Forum, and with the help of the newly elected Prime Minister, Marian Calfa, a Slovak reformist, they were able to remove the communists from power. One of the most important policies pursued by this new group of leaders was the decentralization of political power. Just as Poland and Hungary had done, Czechoslovakia

${ }^{138}$ Goldman, Revolution and Change, 121. 
wanted to encourage political participation from the bottom up. To do this, the new parliament passed legislation to create self-governing institutions at the local, regional and provincial levels. ${ }^{139}$ The main aim behind all of this was to break away from the communist-style system that promoted territorial administration and move towards a reliance on democratically elected local governments. Shortly thereafter, on December 29, Czechoslovakian's had the opportunity to vote for their first president, who was none other than Vaclav Havel, the first non-communist leader in over 40 years. ${ }^{140}$

Some of the initial achievements of the new leadership in Czechoslovakia included the removal of Soviet forces from both Czech and Slovak lands, the expansion of private entrepreneurship, and the establishment of parliamentary elections for June of $1990 .{ }^{141}$ Out of 22 political parties and movements that participated in the June election, the two major winners were Havel's Civic Forum in Czech lands and the Public against Violence (PAV) in Slovakia. Both political movements called for recognition and respect for human rights, the freedom to build a multiparty democracy, the establishment of a free-market economy and the creation of environmental protection laws. ${ }^{142}$ Upon gaining power, Havel and the Civic Forum wanted fundamental economic change but urged caution so that Czechoslovakia would not experience the severe pain of "shock therapy" similar to what had occurred in Poland. Instead, the idea was to approach the situation with a social democratic attitude and provide something of a safety net to the

${ }^{139}$ Kirchner, Decentralization and Transition, 80-82.

${ }^{140}$ Kenney, Burdens of Freedom, 102.

141 Ibid.

142 Goldman, Revolution and Change, 123. 
public in order to minimize the hardships of the transition process. ${ }^{143}$ However, the biggest problem for the new Czechoslovakian government became the disagreements between Czech and Slovak leaders on how this plan should be implemented.

One of the initial issues within the Civic Forum party were the disagreements between President Vaclav Havel and party chairman and Finance Minister Vaclav Klaus. The primary disagreement between the two revolved around how they should move forward with the Civic Forum movement now that it was in power. ${ }^{144}$ For instance, Havel had wanted to turn the Civic Forum into a political entity that could appeal to all, loosely based on shared beliefs and ideas. Klaus, on the other hand, wanted to restructure the movement into a modern political party based on a clearly defined agenda with a registered membership. ${ }^{145}$ Another major disagreement was about how to pursue the reform of Czechoslovakia's economy. As mentioned, Havel had wanted to take a more gradual approach and retain a social safety, specifically for the wageearning groups and salaried employees of major cities. Klaus, in response, argued that minimum restrictions on reform and a fast-paced policy of privatization would benefit the country best. Klaus was also a major spokesman for farmers and the countryside of Czechoslovakia who were interested in getting their products out to Western Europe as soon as possible. ${ }^{146}$ Because of these differences, the Civic Forum split into two separate parties, the Civic Democratic

\footnotetext{
143 Ibid, 124.

144 Kenney, Burdens of Freedom, 109.

145 Stokes, 200.

146 Ibid.
} 
Party (led by Klaus) and the Civic Movement Party (led by Havel). This split would have two major repercussions: the weakening of Vaclav Havel's power and popularity, as well as the weakening of these two parties influence overall in the Czechoslovak state. In this context, a new party and leader arose out of the Slovakian PAV movement.

By the middle of 1991, the Movement for a Democratic Slovakia (MDS) emerged led by Vladimir Meciar. Meciar, a former communist, had become the face of Slovak nationalism and a champion of independent Slovakia. ${ }^{147}$ Both the MDS and Meciar believed that Slovakia's interests could never fully be met by a government predominately run by Czechs, including Havel and Klaus. Another major problem for Slovaks was that the federal government was centered in Prague, which meant that this would be where all of the country's political decisions would come from. Because of his spirited defense of Slovak interests, Meciar became very popular with the Slovak people, and his nationalist agenda acquired widespread support within Slovakia. However, before getting into the "divorce", a look at some of the economic reforms that were pursued by Czechoslovakia in the early 90's must be discussed.

One of the first moves toward economic reform in Czechoslovakia included the closure of inefficient state-owned enterprises and the privatization of thousands of small state-owned retail outlets and shops. ${ }^{148}$ In addition, the new government also removed state control over $85 \%$ of the goods sold in the country, and even limited the money supply to stabilize the Czechoslovak 
currency. ${ }^{149}$ However, even when implemented gradually, these policies still had painful effects on Czechoslovak society.

Some of the initial problems faced during the early economic reforms was a rise in unemployment and a $23 \%$ decline in industrial production in 1991 . In addition, prices of goods rose $25 \%$ in early ' 91 , and by June, they had increased by $45 \% .{ }^{150}$ Privatization itself was also a difficult process; the two most significant barriers to privatization faced by Czechoslovakia at this time were the absence of capital citizens need to buy state-owned enterprises, and the lack of entrepreneurial experience within the country. To combat these problems, the Prague Government introduced a voucher system that allowed citizens to collectively buy and sell shares of different firms within the country. ${ }^{151}$ By January of 1992, 8.7 million Czechs and Slovaks had registered their vouchers with over 400 investment firms. By April of 1993, after the Velvet Divorce, a stock market opened up in Prague, which led to an increase in domestic and foreign investments. ${ }^{152}$ With regard to unemployment, which had reached $6.3 \%$ at the end of 1991, the government adjusted currency exchange rates, approved wage increases, continued state control of some large enterprises and increased its control over rents and utility bills. ${ }^{153}$ The idea behind controlling rents and utilities was to support those who were not making enough at their jobs in the new economy. However, despite these measures, the reforms tended to help more

${ }^{149}$ Goldman, Revolution and Change, 127.

150 Ibid, 127.

151 Jeoffrey Goldfarb, After the Fall: The Pursuit of Democracy in Central Europe (New York: Basic Books, 1992): 90-91.

152 Stokes, 197.

153 Goldfarb, 90-91. 
Czechs than Slovaks, as the economy in Slovakia had a much tougher time privatizing its state-owned enterprises. Czechs in general had more competitive industries that led to more investment from abroad. ${ }^{154}$ Slovaks, on the other hand, were dealing with a slow transition process and an unemployment rate that reached $11.1 \%$ at the end of $1992 .{ }^{155}$ Because of this clear difference in how the two countries were affected by the economic reforms, as well as a strained relationship, after their electoral victories in 1992 both Klaus and Meciar agreed that it was finally time to end the federal state. From Martin M. Simecka, longtime editor-in-chief of SME Slovakia's leading daily newspaper, readers see that at the time "Slovaks felt humiliated by the verbal dominance of Czech politicians, who spoke seemingly rationally but misused their language to suppress the budding Slovak longing for equal rights.." ${ }^{156}$ After December 31, 1992 Czechoslovakia ceased to exist, and was replaced by two separate states. This event would become known as the "Velvet Divorce", due to the non-violent nature of the breakup.

\section{Czech Republic}

\section{Political Transition}

With regard to the Czech Republic's political transition, it is interesting to point out that out of all of the countries discussed, the Czech Republic had one of the most interesting transition periods as their move from a communist

${ }^{154}$ Goldman, Revolution and Change, 130.

155 Ibid, 130.

${ }^{156}$ Martin M. Simecka, "After the Velvet Divorce: Observations of a Double Insider," Visegrad Insight (1) 2012: 52. 
dictatorship to a parliamentary democracy is still highly debated among scholars and citizens. This has to do with the fact that while some, including Minton Goldman sees the transition period as a success because of the political infrastructure that was in place in Prague. This allowed Czechs to simply complete the reforms they had initiated since $1989 .{ }^{157}$ Essentially, all of the important government buildings and facilities were in the hands of the Czechs, meaning that they could spend their time focusing on the economy. However, some, including Political scientist Martin Horak, view the transition period as problematic for several reasons. In his book Governing the Post-Communist City, Horak shows that at the beginning of their tenure the Czech Republic's government, mainly made up of Prague political elites, performed poorly because they were "unable or unwilling to develop and implement systematic policies through open democratic processes in key spheres of public concern." ${ }^{158}$ The two cases Horak points to are the discrepancies over public transportation and the preservation and development in Prague's historic core. With regards to transportation, after the fall of Communist influence in the Czech Republic a large majority of the population wanted to scale back costly communist-era freeway plans within the inner city. ${ }^{159}$ However, the Prague government at the time did not want to reform the transport planning institutions, one of the few institutions that survived the fall of communism, and instead continued with the freeway

${ }^{157}$ Goldman, Revolution and Change, 146.

${ }^{158}$ Martin Horak, "Governing The Post Communist City: Institutions and Democratic Development in Prague" (Toronto: University Toronto Press, 2007), 3. ${ }^{159}$ Ibid, 5. 
plans that had been in process since the mid-1980's. ${ }^{160}$ The second example Horak points to, what to do with Prague's historic core, is somewhat of a similar situation as the government took matters into their own hands again. At the time the government was looking for new sources of revenue and decided to sell historic sights and landmarks within Prague to real estate developers in. Though this decision was seen as very unpopular by civilians, government officials went ahead with plans in order to gain not only revenue for the state but also personal financial gain for themselves ${ }^{161}$. In both cases the Prague government refused to engage in political discussion and debate with the public, specifically civic activist groups, in order to push through their own agenda. The government at the time didn't see these two issues as pressing matters and mainly focused their attention on the political and economic transition of the country. However, because of these actions the Czech government is still seen by many today as ineffective and un-democratic in certain aspects. ${ }^{162}$

Other problems facing the new Czech government actually had to deal with the US and the sale of weapons to unstable nations. In the early 90's, the Czech government was in desperate need of hard currency in order to help move along the privatization of the economy. To solve this problem, the Czech government began selling weapons to politically turbulent countries throughout Southeastern Europe and the Middle East. ${ }^{163}$ With its own interests at stake, the US had asked the Czechs cease these activities, as it was only exacerbating

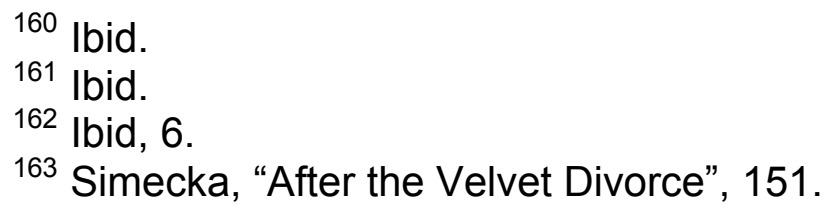


tensions in these regions. In response to the US request, the Czechs promised to no longer sell weapons to these parts of the world in fear of losing aid and support from one of their most powerful allies and most fervent supporters. ${ }^{164}$ In a way, this situation helped develop trust between the two countries, which would soon blossom into the Atlantic relationship still practiced today.

\section{Economic Developments/Struggles}

Unlike its political transition, the Czech Republic's economic transition process went a lot smoother than the other countries in the Visegrad Group. Because of Klaus's economic reform policies in the early years, the Czech people experienced a time of prosperity by the mid to late 90 's. For instance, with the new economic reforms the Czechs were able to establish laws of restitution for those who had lost property under the communist regime as well as laws on privatization and lands for small and large corporations. ${ }^{165}$ Other effects included balancing the national budget, introducing a new tax system based on Western models and finally adopting a social security system that significantly decentralized the former welfare administration. ${ }^{166}$ By 1993, unemployment had fallen below $3 \%$ while inflation was brought down to a manageable level. ${ }^{167}$ Under Klaus's government, the Czech Republic experienced a budget surplus and even a $16 \%$ expansion of Czech exports.

164 Ibid.

165 Stokes, 200.

166 Goldman, Revolution and Change, 200.

167 Ibid, 149. 


\section{Slovakia}

\section{Political Transition}

It has already been mentioned that unlike the other three, Slovakia had a far more difficult time decentralizing political governance and reforming its economy. According to historian Lonnie Johnson the reason behind this can be attributed to two factors. First, after the split with the Czech Republic, Slovakia possessed a "lopsided industrial profile based partly on armament production and traditionally underdeveloped agricultural regions." ${ }^{\text {168 }}$ Second, the rise of both Vladimir Meciar and of Slovak nationalism would greatly effect the political and economic development of Slovakia. ${ }^{169}$ Meciar, a strong, directive, and charismatic leader, was much different from his Visegrad counterparts. Unlike the newly elected leaders of the Czech Republic, Meciar wanted to return Slovakia to a time when opposition was discouraged and political leaders controlled the media. ${ }^{170}$ Suppressing opposition was accompanied by discrimination against minorities within the country, including Czechs, Hungarians, Roma, and Ruthenians. Essentially, the Meciar government didn't see non-Slovaks as natural citizens so their needs and wants would always come second to those of Slovaks, as they had under Josef Tiso during the period of the Slovak state during the Second World War, but without the property confiscations, expulsions and deportations.

168 Johnson, 293.

169 lbid, 294.

170 Kenney, Burdens of Freedom, 114. 
Other issues facing the newly independent nation included the lack of a separate state infrastructure and the problem of international recognition. With regard to infrastructure, as mentioned, the federal Czechoslovak government had been almost entirely located in Prague, so after the split Slovakia had nowhere to conduct its governmental business. ${ }^{171}$ Slovakia was left on its own to build administrative and governmental buildings in its capital of Bratislava, costing the country millions.

In terms of its need for international recognition, Meciar thought it was imperative that he convince others countries that Slovakia was worth investing in. However, unlike the other three Visegrad countries Slovakia turned its attention east toward the Russian Federation. Because Meciar put the brakes on economic reform, his policies were not well received by the EU and US. Knowing this, he sought to build strong relations with Russia in hopes that the former dominant power in the region would not only recognize Slovakia, but also send aid. ${ }^{172}$ However Meciar also had a hidden agenda with regards to his relationship with Russia. Meciar hoped to use his ties with the Russian Federation as a "lever in dealing with the European Union and the United States on trade and security issues." ${ }^{173}$ However, a closer relationship with a Russia itself in political and economic crisis in the 1990s couldn't help Meciar when economic problems caused by his policies occurred. But before jumping into Meciar's economic

171 Ibid, 115.

172 Goldman, Slovakia since Independence, IX.

173 Ibid. 
policies, it is important to highlight some of the achievements that came out of the establishment of an independent Slovakia.

In Slovakia Since Independence, author Milton Goldman explains that while there were plenty of problems plaguing Slovakia in the early 90's, there was progress toward liberalization and democracy, even if it occurred in small steps. Goldman points out that even at a slow pace, the people of Slovakia were ready to move toward liberalism and true democracy. ${ }^{174}$ But it wasn't just the Slovak people; newly elected politicians also began to change how they envisioned government and its relationship to people. Specifically, Slovak politicians who had been completely corrupted and influenced by the Communist party now began to play by a new set of rules set up by the new Slovakian government. ${ }^{175}$ The Slovak parliament was strong enough to block any new dictatorial aspirations, and was able to give the power of the vote back to the people of Slovakia, even if Slovak voters initially supported Meciar. ${ }^{176}$ While this may be far less of a success than that experienced by the other three Visegrad countries, it is still important to recognize Slovakia's trend from communist control to democratic reform. Thus, when the economy in Slovakia began to take a major downturn in early 1994, Meciar's popularity also sank.

\section{Economic Developments/Struggles}

Once the separation of Czechoslovakia occurred, Meciar dramatically slowed down the privatization of the economy. For example, by 1994 only $5 \%$ of

$174 \mathrm{lbid}$ xi.
$175 \mathrm{lbid}, \mathrm{xi}$.
${ }^{176}$ Kenney, Burdens of Freedom, 116. 
state-owned businesses were privatized which led to little foreign investment that year. ${ }^{177}$ In general, the Slovak economy by 1994 could be considered stagnant, as no new policies were coming forward to promote privatization and move Slovakia away from an economy dominated by the state. Because of this, at the end of 1994, Meciar would be unseated as Prime Minister by the Parliament and replaced by Jozef Moravick. Moravick, backed by then president Michal Kovac, had to form a coalition government in an attempt to achieve consensus on how to privatize the economy without worsening the situation. However, in the September '94 elections Meciar and his MDS party were able to gain $35 \%$ of the vote and form a coalition government with the Association of Workers of Slovakia, a far right party and Meciar returned as Prime Minister. ${ }^{178}$

With regards to the economy, Slovakia moved forward with economic reform, though it was still at a slower pace than in the other Visegrad countries. Earlier, a major success occurred in 1993 when the IMF gave Slovakia $\$ 90$ million in loans in order to support its currency reserves, which now allowed banks to provide more credit to privatizing companies. ${ }^{179}$ Other accomplishments made by the Slovakian government included cutting back on the increasingly expensive social safety net and subsidies to inefficient state-controlled enterprises. Finally the government pursued policies that would "curtail imports from hard-currency countries to bolster its own currency, with a view eventually

177 Goldman, Revolution and Change, 146.

178 Kenney, Burdens of Freedom, 115.

179 Goldman, Revolution and Change, 148. 
to making it convertible." ${ }^{\prime 180}$ An example of this would be the $20 \%$ surcharge imposed on imports from the EU and European Free trade Area. ${ }^{181}$ These policies, though painful at first, would lead Slovakia to becoming one of Europe's most successful economies by the early 2000's. However, this discussion will be saved for the last chapter that deals with present developments in the Visegrad countries.

\section{The Odd Man Out}

In Chapter 4 the reader will notice that when discussing Visegrad's move into NATO with the help of the US, Slovakia is mentioned very little. This is because Slovakia, led by Meciar until 1998, would fail to address its institutional problems, there by disqualifying itself from the enlargement process in the late 90's. Reasons behind this, as mentioned above, included Meciar's antidemocratic approach to politics, as well as illegal activities the former Prime Minister was involved with. ${ }^{182}$ Kenney shows that allegations of kidnapping, torture, and even murder were a common practice during Meciar's tenure. When word of these activities reached both NATO and the US there was no one left to support Slovakia's candidacy to the military alliance. However, a Visegrad Presidential Report from 1999 shows that the other three countries "called upon the Alliance to admit another V4 country, Slovakia, as soon as possible." ${ }^{183}$ What

\footnotetext{
180 Ibid.

181 Ibid.

182 Roland D. Asmus, Opening Nato's Doors: How The Alliance Remade Itself for a New Era (New York: Columbia University Press, 2002), 154-155.

${ }_{183}$ The Visegrad Group: The Czech Republic, Hungary, Poland and Slovakia. "1999/2000 Czech Presidency: Annual Reports on the Activities of the Visegrad Group." International Visegrad Fund.
} 
this shows is that while the V4 was not necessarily on the same timeline for accession into NATO and later the Atlantic World, they were all still united on the issue that every member of the V4 needed to be secured.

\section{Conclusion}

This chapter discussed the transition processes within the Visegrad countries following the collapse of communist rule. Many political and economic issues arose during the transition process, but these countries were able to move forward at different paces as governments and politicians fought hard for implementation of their policies. While many of these policies may have been controversial, some would greatly benefit the future of these countries. One of these benefits was attracting the attention and favors of Western countries, including members of the EU and more importantly the US. The political leadership of one country, Slovakia, initially made the decision that it wasn't interested in pursuing the same path as its neighbors and instead chose a much slower and politically less painful route. Because of this choice, as well as the authoritarian style of Vladimir Meciar and his MDS government, western countries would be more hesitant in extending an invitation to Slovakia into the Atlantic world, most notably membership into NATO. Following a change in political leadership, however, by the mid-2000's Slovakia would go on to become an economic success story and a member of both NATO and the European 
Union. Having established this context of political and economic transition, attention can now be turned to the U.S.'s role in Central Europe's move into the Atlantic world. 


\section{Chapter 3: The Clinton Administration}

Atlanticism reached its apex during the Clinton Administration and continued to dominate US foreign policy until about 2000, when the U.S. Supreme Court declared George W. Bush the controversial winner of that year's presidential election. It was during the Clinton years that the relationship between the US and the V4 was at its strongest. This had much to do with the fact that Clinton was something of a liberal internationalist in that he wanted to support democracy and economic reforms in to the newly established V4. This chapter will primarily focus on the attitudes and goals of the Clinton Administration to better understand the significance of this relationship. Furthermore this chapter will examine the policies put in place that helped bring the former Eastern Bloc countries into the Atlantic world. It will also be imperative to take a look at the role of the Yugoslav Wars, as they would increase the U.S.'s attention to the Central European region. By analyzing and critiquing U.S. policies and the role of the Yugoslav Wars, it will be seen that in many ways it was because of their ties to the US that the V4 was better able to engage the European Union, and indeed the wider world. However, before delving further into this topic, it is important to note that glimpses of Atlanticism can be seen between the US and V4 countries long before the Clinton Administration.

\section{Atlanticism before Clinton}

\section{From Wilson to the Cold War}

Political Scientist Bennet Kovrig shows that U.S. and central European relations began at the end of W.W. I when President Woodrow Wilson issued his 
vision of national "self-determination" which was the belief that states had the right to determine their own future without outside interference. ${ }^{184}$ Selfdetermination would become a backbone philosophy to US foreign policy and would be used to "legitimate its participation and forge a more peaceful and democratic order in Europe." ${ }^{185}$ An example of this would be in the form of Wilson's 14 point plan which would go on to influence many East/Central European states who believed in "the universality of the principle of justice to all peoples and nationalities, and their right to live on equal terms of liberty and safety with one another, whether they be strong or weak." ${ }^{186}$ However, while the U.S. talked of supporting East and Central European states right to selfdetermination, what actually occurred was a period of isolationism that undermined this practice. With this lack of support East and Central European countries would fall under the influence of the future powers of the Soviet Union and Nazi Germany. The U.S. would not engage with these countries again until the start of the Cold War.

Both Kovrig as well as historian Walter Hixson show that during the Truman and Eisenhower administrations, relations with central Europe would again come to the forefront of U.S. foreign policy. Interactions would come in the form of the policies enacted during these administrations that were a mix of tactical and "psychological warfare" policies. ${ }^{187}$ Kovrig, shows us that three

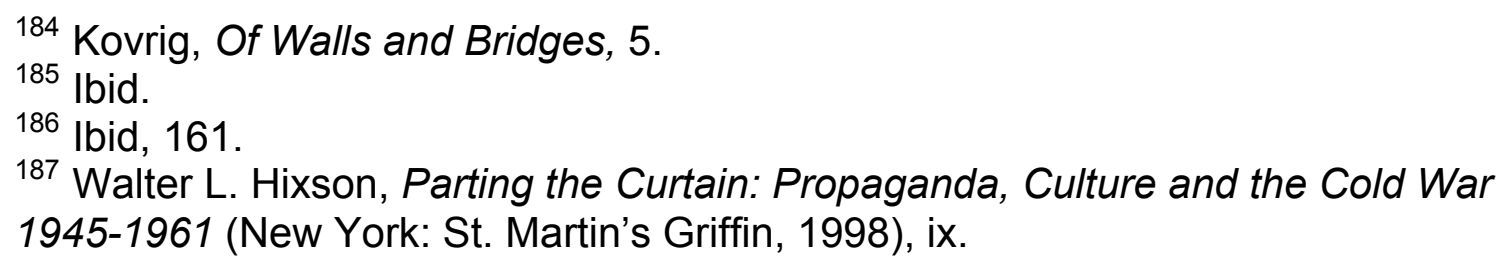


policies used by the U.S. at the beginning of the Cold War included the "Roll back," "Liberation," and "Captive Nations" policies. All three of these policies were based on propaganda, a cornerstone to US foreign policy during this period, that both Americans and East/Central Europeans should view the Soviet Union as an evil occupying force. ${ }^{188}$ The rollback policy was meant as a way to try and gradually move the Soviet line back through means of negotiation, economic sanctions etc. ${ }^{189}$ Liberation policy was to be used to promote unrest within a certain state or region and promote insurgency in order to overthrow Soviet forces. ${ }^{190}$ Finally, the captive nations policy was just a general way to paint the Soviet Union as an evil occupying force and would be used to "reassure eastern Europeans and generate a spiritual power that would ultimately overcome Soviet dictatorship." ${ }^{191}$ However with regards to actual military engagement, Kovrig points out, that in reality "it is highly unlikely that any American president would ever have seriously considered taking such a risk for the sake of freeing a small, faraway country." ${ }^{192}$ Because of this U.S. foreign policy would turn to other means of trying to overthrow the Soviet Union. In his book Parting the Curtain, Walter Hixson shows how the U.S. used gradual cultural infiltration to try and destabilize the Soviet and eastern European Communist party. Examples of cultural infiltration included trying to advertise to citizens in occupied countries through radio and television broadcasts the

\footnotetext{
189 Ibid.

$190 \mathrm{lbid}, 44$.

191 lbid, 51

192 Ibid, 96.
}

${ }^{188}$ Kovrig, Of Walls and Bridges, 51. 
wonders of western consumer culture including Pepsi-Cola, Cadillac cars, designer clothes and the beauty of fashion models. ${ }^{193}$ The point of all of this was to try and show East-Central Europeans that they too could have a life filled with exotic consumer goods if only they could overthrow their occupying government. This would all amount to a breakthrough in US-Soviet relations when on January 27, 1958 a cultural exchange agreement was signed. ${ }^{194}$ This would lead to an exchange of "radio and television broadcasts, feature and documentary films, students and professors, artists and writers, scientists and agricultural experts, athletes, youth and civic groups" to name a few. ${ }^{195}$ By the summer of 1959 an American National Exhibition was scheduled in Moscow. This event would be used as an opportunity to display the very best of western consumer culture to the Soviet Union and it's republics. ${ }^{196}$ However, at the end of the Eisenhower administration both the tactical and psychological warfare policies would be greatly buried due to a number of reason including the fact that propaganda by this time had greatly calmed down and the U.S. could no longer justify using policies that incited violent revolutions within a country. What replaced these policies was just a military build by both superpowers that would lead to a nuclear arms race. It would not be until the 1970's that U.S. and central European relations would resurface.

${ }^{193}$ Hixson, Parting the Curtain,

194 Ibid, 153.

195 Ibid.

196 Ibid, 162. 


\section{The Carter Administration}

The Cold War and relations between the US and the Communist world drastically changed after the early 1970's due to the policy of détente pursued by the Nixon and Ford Administrations. Détente was a policy that strived to ease tension between the US and the Soviet Union in order to build common ground between the two superpowers. An example of this can be seen from the 1975 Helsinki Accords where 35 nations, including the US and USSR, signed agreements, known as "baskets" to ease tensions between the Western and Communist worlds. ${ }^{197}$ One of the most important agreements, known as "basket 3", stated that the Soviets had to recognize "'human rights, including the freedom of emigration and reunification of families divided by international borders, cultural exchanges and freedom of the press." ${ }^{\text {198 }}$ I only mention this basket because it would prove to be significant in inspiring pro-human rights groups throughout Central and Eastern Europe which is important to understanding the 1989 revolutions previously discussed in Chapter $2 .{ }^{199}$

Because of this détente, future administrations would be able to have more access to not only the Communist world, but also specifically Central Europe. Historian Minton F. Goldman suggests that the Atlanticism between the US, and specifically the future V4 countries had its roots in the late 1970's when President Jimmy Carter was in office. Goldman believes that during Carter's

\footnotetext{
${ }^{197}$ Walter LaFeber. The American Age: U.S. Foreign Policy at Home and Abroad since 1896. New York: Norton, (1994), 671-672.

198 "Milestones 1969-1976: Helsinki Final Act 1975," Office of the Historian, US Department of State, 10 June, 2015. https://history.state.gov/milestones/19691976/helsinki. 199 Ibid.
} 
administration, the president's foreign policy goals focused heavily on human rights violations of the 1975 Helsinki Accords, which had been meant to serve as the symbolic culmination of détente. ${ }^{200}$ By focusing on human rights violations, Carter was able to "encourage an expansion of dissident activity and the emergence of a political opposition." ${ }^{201}$ Carter visited Warsaw, Poland in 1977 in hopes of voicing his concern for human-rights violations, as well as to engage the Polish government which was then led by Communist Party First Secretary, Edward Gierek. ${ }^{202}$ In doing this, Carter was giving support to opponents of the ruling regime. While these initiatives may have seemed to have had little effect at the time, they helped to forge the foundation of the future relationship between the US and V4 countries. They instilled a connection between Central Europe and the US, and ultimately, influenced the decision of the region's states to reach out for help when the Communist regime collapsed.

However, it is important to note that unlike Bill Clinton, Carter had surrounded himself with foreign policy advisors who were often at odds. On the one hand, there was Secretary of State Cyrus Vance, who championed the continuation of detente. ${ }^{203}$ Vance believed it was wrong to approach foreign policy with a combative attitude. Instead, Vance argued that it would be more effective if Carter's administration took a step back and consider the world as a highly complex and developing place.

${ }^{200}$ Goldman, Revolution and Change, 19.

201 Ibid, 19.

202 Bennett Kovrig, Of Walls and Bridges: The United States and Eastern Europe, (New York: New York UP, 1991), 129.

${ }^{203}$ LaFeber, 681-82. 
At the same time, President Carter also received foreign policy advice from Zbigniew Brzezinski, the National Security Council Director. Brzezinski, unlike Vance, believed that while détente was important, the US should also pursue more comprehensive and reciprocal policies that would "enhance peace and promote change within the communist system." ${ }^{204}$ Specifically, Brzezinski was interested in steering the Carter administration into taking a more activist approach to the region of Central and Eastern Europe. The idea would be to expand relations with Central and Eastern European countries "for its own sake and not merely as a by-product of détente with the Soviet Union." 205 This would include undermining Soviet domination and hardline communist regimes by supporting opposition movements like KOR and Charter 77 that called upon their states to respect the human rights agreements they had signed. ${ }^{206}$ Brzezinski would also advocate US support for Radio Free Europe, which he saw as an instrument that could bring about change in the region. The main point of Brzezinski's policies revolved around small and incremental, not radical, change that would help destabilize Soviet domination. ${ }^{207}$

Swayed by the varying views of Vance and Brzezinski, Jimmy Carter's foreign policy sought both the continuation of détente with the Soviet Union as well as the support for human rights within the Soviet bloc. Ultimately, this lack of a singular vision of foreign policy, on top of Carter's inability to resolve the Iran

${ }^{204}$ Kovrig, 125.

205 Ibid.

${ }^{206}$ LaFeber, 682.

${ }^{207}$ Kovrig, 125-129. 
hostage crisis, has largely shaped our view of the Carter Administration as ineffectual.

\section{The Reagan Administration}

During the first half of the Regan administration, relations between the US and Communist world reverted largely back to the pre-détente era of the Cold War. Détente was no longer the modus operandi of Washington; instead, Reagan's new foreign policy would be built on four cornerstones. The reason for abandoning détente and adopting a new foreign policy was due to the crisis that culminated in Poland in December of 1981. Historian Bennett Kovrig shows that due to the rise of the newly formed Solidarity Trade Union that began to campaign for more freedoms within Poland, both the Kremlin and then leader of Communist Poland General Wojciech Jaruzelski declared a "state of war" and placed Poland under martial law. ${ }^{208}$ The reason behind this was to stop the Solidarity movement from gaining further influence in the communist-dominated political sphere. The Party would go onto to arrest many activists and leaders of the trade union. However the Reagan administration, specifically those in the Pentagon, saw this as opportunity to press for a "tougher policy of economic isolation and destabilization of the Soviet Bloc." ${ }^{209}$ What would follow was a deterioration of Soviet and US relations that would lead to economic sanctions as well as beefed-up military spending. In Walter LaFeber's The American Age, the author describes the four cornerstones of Reagan's new policy, explaining that the first cornerstone was that Reagan believed that America needed someone

${ }^{208}$ Kovrig, 138.

209 lbid, 141. 
who had a commanding presence. ${ }^{210}$ Reagan sought to strengthen his presidential powers, thereby allowing him to increase military spending; rearmament, of course, flew in the face of détente.

The second cornerstone was reviving the age-old anti-communist narrative. Instead of taking a constructivist stance, similar to what the former Secretary of State Vance, Reagan saw Communism as the source of the world's problems. In 1980, Reagan stated that, "The Soviet Union underlies all the unrest that is going on. If they hadn't engaged in their game of dominoes, there wouldn't be any hot spots in the world." ${ }^{211}$ The notion of a "Domino Theory" is reminiscent of the rhetoric used by former president Harry Truman in the late 1940's that justified the US policy of containment at the outset of the Cold War. This theory stated that if communism wasn't contained and one country fell to communism, then the surrounding region would also fall into its sphere of influence. What is critical to note is that when Jimmy Carter left office the American people, as well as the outside world saw US foreign policy as weak and lacking in purpose. In many ways, Reagan was wise to revert to this distrustful, and at times, combative stance towards Communism, as it had always been a popular one. In this way, Reagan was able to use the long-time fear of communism, which at times degenerated into hysteria, to propel himself into becoming one of the most popular political figures in U.S. history.

The third cornerstone of Regan's foreign policy agenda was to highlight the distinction between "authoritarian" and "totalitarian" governments. Reagan's

${ }^{210}$ LaFeber, 704
${ }^{211}$ lbid. 
U.S. ambassador to the UN, Jeane J. Fitzpatrick, had argued at the time that the difference between the two laid in the fact that "authoritarian" governments, such as those in South Africa and Argentina, were more stable, more likely to evolve into future democratic systems because of their positive view of capitalism and foreign investors, and in general they tended to have a more favorable relationship with the US. ${ }^{212}$ "Totalitarian" governments on the other hand, such as those of the Soviet Union and China ruled by communists, showed less signs of democratizing, despised capitalism, and opposed U.S. interests. ${ }^{213}$ With this mindset, Reagan restarted the arms race with the Soviet Union.

Finally, Reagan's fourth cornerstone of foreign policy pledged to raise military spending by $40 \%$ between $1980-84 .{ }^{214}$ This included a massive nuclear build up and expanding the Navy to 600 ships. It is interesting to point out that by 1981, when Reagan took office, the CIA had already knew that the US was already equal, if not superior to the Soviet Union in military capabilities, ${ }^{215}$ which begs the question, why did the United States increase military spending?

During Reagan's first term in office, U.S. foreign policy went back to predétente years. However, during his second term in office the relationship between the US and Soviet Union improved. When Mikhail Gorbachev came to power in 1985, the Soviet Union was in a downward economic and political spiral that quickly needed to be fixed. During his time as General Secretary of the Soviet Union, Gorbachev would promote a new Soviet policy that preached "unity

${ }^{212}$ Ibid.

${ }^{213}$ Ibid.

${ }^{214}$ Lafaber, 207.

${ }^{215}$ Lafaber, 208. 
in diversity" and called for the reopening of dialogue with the west. ${ }^{216}$ This would eventually lead to arms reduction talks between the two superpowers which many had thought unimaginable just a few years before. Another major improvement was the reestablishment of trust between the Soviet Union and US, which would in turn reopen discussions on trade. ${ }^{217}$ However, even with a new take on how the Soviet world could be reformed Gorbachev's ideas wouldn't be able to curb Central and Easter Europe's desire for freedom.

\section{The Bush Administration}

By the time George H.W. Bush had entered office as president in 1989, the Soviet Union and Eastern Bloc were on the verge of collapse. With this in mind, Bush knew that he would have to take a stance on whether or not to help the soon to be newly independent countries. Initially, the Bush Administration was skeptical about the newly elected leaderships coming out of Central Europe and the possibility of democracy and capitalism taking root. This may have had something to do with the fact that many people at the time believed that the Soviet Union under Gorbachev would successfully reform itself and preserve communist rule. Bush called for a continuation of the arms negotiations as well as the reform process in the Eastern Bloc countries. ${ }^{218}$ However it should be noted that Bush had to tread a fine line when it came to supporting Central and Eastern European countries so as not to anger the Soviets. President Bush

216 Kovrig, 310-311.

217 lbid, 282.

218 Kovrig, 152. 
stressed that if change was going to come to Central and Eastern Europe it would have to come from within. ${ }^{219}$

When the Soviet Union collapsed in 1991, it came as a shock; nobody thought that the regime was ever going to fall. Because of this unexpected twist, it took time for U.S. foreign policy to adjust to the new situation. President Bush was hesitant; he wanted to see if both Central and Eastern Europe could make the necessary reforms rather than simply rely on large infusions of foreign capital. ${ }^{220}$ However, this is not to say that the future Visegrad countries didn't receive any help from the U.S. in the early 1990's. After the fall of communism and the Soviet Union, many in Congress came out in support of the Central and Eastern European transition to political democracy and free-market economies. Specifically, former Senator Bob Dole became an avid supporter of US aid to the future V4 countries. However, even with this support in Congress, the Bush Administration had other troubles to worry about. During this period, the Bush Administration became embroiled with issues in the Persian Gulf and Latin America, as well as issues resulting from the break-up of the Soviet Union and Yugoslavia. Because of these concerns, the amount of time and resources that could be dedicated to helping Central and Eastern Europe were limited, although President Bush was able to urge the International Monetary Fund (IMF) to "change its lending regulations so that it could provide extra money to pay for high-priced oil imports." 221 During the Persian Gulf War (1990-92), Kuwaiti and

${ }^{219}$ Ibid, 154

${ }^{220}$ Goldman, Revolution and Change, 47.

221 lbid. 
Iraqi oil exports were disrupted, which created an energy crisis in Europe, leading the price of oil to skyrocket. Bush recognized the risk this represented and knew he had to step in so that the newly established democracies of Central Europe could sustain themselves.

As discussed above, the relationship between the US and the V4 actually has its roots in Wilson's support for self-determination; from here relations between the two regions would not see a significance of change until the outbreak of the Cold War. A period of militarization and psychological warfare would occur during the Truman and Eisenhower administrations only to be reduced to a nuclear arms race. It wouldn't be till the Helsinki accords in the 1970's that the US and the Carter Administration would be able to begin building bridges between America and Central Europe. However, after this period the US went right back to old Cold War tactics until the rise of Gorbachev presented new opportunities for negotiations and engagement. It was not until after the collapse of Communism in late 1989 and the 1990's that the US would again begin to provide tangible support to the future V4 countries. With this understanding, focus can now turn to the administration that took what was perhaps the strongest stance on what the US's role should be with regard to the future of Central Europe.

Clinton and Visegrad

By reading the autobiographies of former President Bill Clinton and his former Secretary of State, Madeline Albright, it is evident that these two leaders had numerous ties and reasons to help bring the V3 (initially just Poland, 
Hungary, and the Czech Republic) in to the Atlantic World. With regard to Clinton, the former President had spent the better part of a year (1969-70) in his youth traveling throughout Europe and the Eastern Bloc, and held places such as Prague and Budapest close to his heart due to his personal experiences with the people and their culture. In Clinton's autobiography, My Life, the former president looks back with particular fondness on his friendship with a Czech colleague he had met while studying at Oxford University in England, Jan Kopold. ${ }^{222}$ Later, Clinton spent a week in Prague with Kopold and his family, who soon came to see Clinton as another son. ${ }^{223}$ This experience would have a major impact on his future foreign policy as this trip came to hold a special place in his heart. It also showed Clinton that the US could be seen as a beacon of hope for people, particularly in the aftermath of the Prague Spring and Soviet invasion, struggling under the yoke of communism. ${ }^{224}$ However, as Ronald Asmus points out, while Clinton's administration claim to have altruistic motives it is important to point out that the collapse of the Soviet Union created a geo-strategic vacuum in Central and Eastern Europe that provided an opportunity for the US to expand its political and military influence. ${ }^{225}$ It is imperative that while reading through information given by Clinton and his administration, even if there motives for wanting to help the V4 are sincere, to remember that NATO enlargement at this time was also part of a larger battle to show the world what the US stood for. This event would

${ }^{222}$ Nigel Hamilton, Bill Clinton: An American Journey (New York: Random House, 2003), 219.

${ }^{223}$ Ibid.

${ }^{224}$ Bill Clinton, My Life (New York: Knopf, 2004), 569.

${ }^{225}$ Asmus, Opening NATO's Doors, xxv. 
also help solidify the US's relevance and role as the dominant military force in the world which would influence history and events in years to come. Before diving into the policies and work that led to the acceptance of Poland, Hungary, and the Czech Republic into NATO in 1999, an understanding of why foreign policy toward the V3 countries changed from one of mostly ambivalence to one of focused interest.

\section{Factors for Change:}

Before the NATO invitation in 1997, there had been many arguments for and against the idea of expanding NATO membership to Poland, the Czech Republic and Hungary. In The Burdens of Freedom, historian Padraic Kenney shows that four specific factors would lead to a major change in favor of NATO expansion to these countries. The First, as mentioned previously, was that unknown Russian intentions frightened both Central Europe as well as the US. At the time, many believed that Russia needed to be "kept in check" so that it could not form a new version of the Soviet Union. ${ }^{226}$ There was also the argument that there could not be European Security without Central and even Eastern Europe.

Secondly, there was an element of U.S. domestic concern that also played a hand in the U.S. pushing for Central Europe's acceptance into NATO. While Clinton's actions to bring the V3 countries into NATO seem to be based on sincere motives, one must ask if this move was also influenced by Clinton's own goal of making a bold political move that would solidify his place in history. ${ }^{227}$ It should be pointed out that Clinton was also pushed by his own administration to

${ }^{226}$ Kenney, The Burdens of Freedom, 136.

${ }^{227}$ Ibid, 137 
prove "his and his party's foreign party credentials." ${ }^{228}$ Public opinion at the time tended to favor Republican views on issues of foreign policy so this can certainly be seen as a chance for Clinton to show how his party was up to the task of dealing with foreign affairs. Shortly after coming into office in 1993, Clinton stated that he wanted to "create a Europe that was united, free, democratic, and secure for the first time in History." 229 Once again it is imperative to be aware that NATO expansion was a way to solidify the US's role as a world police force. Whether his motives were based on personal and strategic goals or goals that pursued a stronger relationship with Central and Eastern Europe is up to future historians to decide.

The third factor that contributed to the increase of U.S. attention toward Central Europe was the Yugoslav Wars of the 1990's. As will be discussed, the role of some in the V3 during the Yugoslav Wars, as well as their strategic locations, made the U.S. and NATO very interested in building alliances that could aid in ending the crisis.

Finally, as discussed, the Clinton Administration saw that the EU was in no way ready to extend membership to the newly independent countries. This meant that help would have to come from the U.S. and Clinton would make it one of the cornerstones of his foreign policy initiatives while in office.

\section{A New Foreign Policy}

In June of 1993, the Clinton Administration had approved a new foreign policy initiative directed specifically at Central and Eastern Europe. Clinton's new

${ }^{228}$ Asmus, Opening NATO's Doors, 27.

${ }^{229}$ Clinton, 569. 
policy, broadly defined, was based in bolstering democracies in all the newly independent countries, reducing trade barriers in order to help stimulate economic growth, and rewarding nations who succeeded in completing economic reforms. ${ }^{230}$ Specifically, the policy would be guided by four principles that, if implemented correctly, would place Central and Eastern European countries on the road to membership in NATO, the organization that would both guarantee their security and usher them into the Atlantic world. The first principle was to establish that NATO was the only organization in Europe that could safeguard European security. ${ }^{231}$ According to Asmus at the time the view was that "NATO must be as effective in dealing with future threats as it was in meeting the Soviet threat during the cold war."232 This meant that no other organization or institution could replace or challenge the military capability that NATO had in Europe. Such a distinction would help prevent another cold war from breaking out in which two military alliances compete with each other.

The second principle behind Clinton's new foreign policy stated that it would not be fair or right for NATO to deny acceptance to the newly liberated Eastern Bloc countries and Soviet Republics. ${ }^{233}$ If NATO was going to fight for peace and democracy in Western Europe, then the next natural step would be to include the countries of Central and Eastern Europe, as they too were striving for political and economic freedoms. As will be discussed, Madeline Albright and

${ }^{230}$ Madeleine Albright, Madam Secretary: A Memoir (New York: Miramax, 2003), 167.

${ }^{231}$ Ibid.

232 Asmus, Opening NATO's Doors, 19.

${ }^{233}$ Albright, Madam Secretary, 167. 
John Shalikashvili also had deeply personal reasons for why they wanted to ensure that the $\mathrm{V} 3$ countries were brought into the secure realm of the Atlantic world.

The third principle guiding Clinton's policy was to use the prospect of joining NATO as a way to convince countries to "ensure civilian command of their armed forces, liberalize their economies and respect rights of minorities." ${ }^{234}$ This was a crucial element to Clinton's policy, as the region's communist era's military forces had served as instruments in the hands of party leaderships. Ensuring that the military was under civilian control of largely non-partisan political institutions meant that authoritarian regimes could not easily use it as a means to take power. With regard to minorities, this principle was designed to ensure that questions like what to do with the Roma would be handled delicately and with respect for their basic human rights.

Finally, Central and Eastern Europe had to understand that NATO enlargement needed to be a gradual process. ${ }^{235}$ This is largely because once the US announced its plan for NATO expansion, the Russian Federation, and specifically Russian Federation President Boris Yeltsin, became worried that the Western world would try and build a military wall between Russia and Europe. One of the major arguments against NATO expansion at the time was that wherever the NATO alliance line ended, Russia would be sure to secure and fortify the neighboring area to the east. ${ }^{236}$ President Clinton took this matter to

234 Ibid.

235 Asmus, Opening NATO's Doors, 50.

${ }^{236}$ Kenney, The Burdens of Freedom, 136. 
heart, constantly reassuring Yeltsin that Central and Eastern Europe's security and stability within NATO also served Russia's interests.

Thus, Clinton had a clear-cut strategy on how to deal with the former Communist countries as they sought to join the Atlantic World. Unlike his predecessors, Clinton was ready to build a new bridge between the East and West and unite these worlds into one functioning and peaceful international system. Also, unlike President Carter, Clinton had surrounded himself with largely like-minded foreign policy advisors who would play a critical role in developing the relationship between the US and V4 countries.

\section{Albright and Shalikashvili}

As mentioned, former Secretary of State, Madeline Albright, and former Chairman of the Joint Chiefs of Staff, John Shalikashvili, had a special interest in the successful integration of the V3 countries into the European Community and Atlantic world. Both Albright and Shalikashvili had been born in Central Europe but were forced to escape in order to survive. Albright, who refers to herself as a "daughter of Czechoslovakia," was driven out in 1938 because of her family's fear of the invading Nazi army. ${ }^{237}$ Because of this, Albright had always yearned to know more about her homeland, which led to a long career of studying and teaching about the impact of Communism on the Eastern Bloc. It is interesting to note that during her doctoral program she would be advised by former National Security Council Director Zbigniew Brzezinski and would also be heavily

237 Albright, xiii. 
influenced by none other than Vaclav Havel, former President of the Czech Republic.

Albright had met Havel in the late 1960's when he was known as a successful playwright and the emerging leading dissident against the Communist regime in Czechoslovakia. ${ }^{238}$ Over the years, the two stayed in touch with Albright even writing her dissertation, supervised by Brzezinski, on the events surrounding Havel and Czechoslovakia's fight for freedom. ${ }^{239}$ Because of this close-knit relationship, President Havel had Albright serve as his translator and advisor when he first visited the US in $1989 .{ }^{240}$ Later, in 1990, Havel brought his friend to Prague in order to help him set up the new presidential office at Hradčany castle. ${ }^{241}$ In 1993, Albright arranged a large party in Washington DC to celebrate Havel's appointment as President of the Czech Republic. ${ }^{242}$ The guest list included the President and First Lady of the US, who were entertained by a performance by the young jazz guitar virtuoso, Kevin Whitfield (a favorite of Havel's). ${ }^{243}$ It was rumored that in September of 1998, Havel even suggested that Albright succeed him in becoming the next President of the Czech Republic. ${ }^{244}$ However, the Clinton Administration had other plans in store for Mrs. Albright. Because of her background, knowledge, love of the region, and close

238 Thomas Blood, Madam Secretary: A Biography of Madeline Albright (New York: St. Martin's, 1997), 52.

${ }^{239}$ Madeline Albright, The Role of the Press in Political Change: Czechoslovakia 1968 (Chicago: Columbia University 1976).

240 Ibid.

${ }^{241}$ Michael Dobbs, Madeleine Albright: A Twentieth-century Odyssey (New York: Henry Holt, 1999), 341-42.

242 Blood, 52.

243 lbid, 55.

${ }^{244}$ Dobb, 409. 
bond with President Vaclav, it is no wonder that President Clinton appointed her Ambassador to the United Nations in 1993 and Secretary of State in $1997 .{ }^{245}$

The other main actor in the strengthening of relations between the US and V4 was General John Shalikashvili, known to his friends as "Shali." Shalikashvili, like Albright, had been born in Central Europe and was also forced to flee his homeland in Poland in 1944 due to the advancing Red Army. ${ }^{246}$

Shalikashvili is also famous for being the father of the plan that would help get Central and Eastern Europe on the road to NATO acceptance, known as the Partnership for Peace (PFP). The PFP was essentially a way for the newly independent countries to "participate in military training exercises with NATO countries."247 If countries were able to upgrade their military, maintain peaceful relations with their neighbors, and solidify democratic institutions, then it would be possible for the PFP countries to apply for full NATO Membership. ${ }^{248}$ However, it should also be noted that the PFP also required members to "respect the inviolability of borders, something Bratislava had been trying to get Hungary...to do for some time." ${ }^{249}$ This would also help resolve the long-standing differences between Hungary and Slovakia over the treatment of minorities. ${ }^{250}$ The other countries that were welcomed into the PFP included Poland, Czech

245 Kenney, The Burdens of Freedom, 137.

246 Dobb, 168.

247 Ibid.

248 Ibid

249 Goldman, Slovakia since Independence, 156.

250 Ibid. 
Republic, Romania, Slovenia, Bulgaria, and Albania. ${ }^{251}$ However, not all of the invited members were excited about this new proposition.

\section{Selling the Partnership for Peace}

One of the more arduous tasks in forging the Atlantic relationship between the US and V3 was to convince the former Communist bloc countries that the PFP was the first step in coming into the European and Atlantic Communities. Upon hearing about the PFP, Polish President Lech Wałęsa called it "blackmail" and said the plan was "too little". ${ }^{252}$ Wałęsa clearly wanted Poland to be accepted as a full member of NATO immediately in order to guarantee Poland's security from historically hostile neighbors, primarily the Russian Federation. Aware of this skepticism, President Clinton sent Albright and Shalikashvili all over Central and Eastern Europe to convince the invited countries to partake in this plan prior to the January 1994 NATO summit in Brussels. ${ }^{253}$ This head start was critical if the PFP was to be considered and established at the summit meeting. It was therefore up to Albright and Shalikashvili to convince Poland, Hungary and the Czech Republic to join the PFP. Shalikashvili, known for being brief, laid out the PFP outline by stating:

"You will come to Brussels... and we will give you a desk, a filing cabinet, and a phone. We'll have people there with whom you can consult and plan. We'll learn how to operate together as a military team. And we'll develop communications and other equipment that are interoperable." ${ }^{254}$

${ }^{251}$ Dobb, 168.

252 lbid, 169.

${ }^{253}$ Asmusm Opening NATO's Doors, 58.

${ }^{254}$ Albright, 169. 
Within a short period of time, Albright and Shalikashvili were able to not only persuade Wałęsa, but also the rest of the invited PFP countries to sign agreements with NATO that would lead to future membership in the organization. ${ }^{255}$ They achieved this by assuring the political leaders of the PFP countries that this would be the best and quickest way to get into NATO officially, thereby ensuring their security. It is clear that Albright and Shalikashvili could not only relate to, but also communicate with Czech and Polish leaders in their own tongues that the US was deeply invested in the future of this region; why else would Clinton send two of his most trusted advisors? By January 10, 1994, NATO had approved the PFP in Brussels, and the $\mathrm{V} 3$, as well as much of the rest of Eastern Europe, were well on their way to integrating into the Atlantic World. ${ }^{256}$ However, not everyone with interests in the region was convinced that the PFP would be good for Central and Eastern Europe.

\section{The Yeltsin/Russian Dilemma}

Today, critics of this strategy like Polish diplomat Andrzej Ananicz claim that the PFP was just a way that the US could derail or stall the V3 from entering into NATO and the Atlantic world. ${ }^{257}$ However, what Ananicz fails to realize is that the PFP was not only executed for the benefit of the V3 and Eastern Europe; rather, it was also a way to appease the Russian Federation, which was afraid that the expansion of NATO could lead to another cold war. Throughout the entire PFP process, the Clinton Administration was concerned that NATO

\footnotetext{
255 Ibid, 168.

256 lbid, 169.

257 Ananicz.
} 
expansion might be seen as "a new division of Europe farther to the East."258 This proved to be a valuable insight on Clinton's part; upon hearing about the PFP, Russian President Boris Yeltsin immediately criticized this plan and claimed that the US was trying to start a "Cold Peace" by rushing to enlarge NATO into Central and Eastern Europe. ${ }^{259}$ It was up to Clinton himself to convince the Russian President that the PFP was simply a way to secure the new European countries' democratic systems, and make clear that it was in no way aimed at Russia. However, by looking closer at the situation, it becomes evident that Yeltsin had no choice but to criticize the PFP plan because of an upcoming election in 1996. Yeltsin knew that if he remained silent about the PFP and the prospect of NATO enlargement, his political opponents could use this as a way to make Yeltsin look weak. ${ }^{260}$ Because of this, Clinton personally went to Helsinki in 1997 to discuss NATO expansion with Yeltsin. ${ }^{261}$ In order to persuade Yeltsin to accept NATO enlargement, Clinton cleverly came up with a strategy that would sweeten the deal. Clinton wanted to offer Russia a spot in the G-7 Summit as well as the World Trade Organization (WTO). ${ }^{262}$ Before eventually accepting these terms, Yeltsin secretly asked Clinton to limit future expansion of NATO to former Warsaw Pact countries and to exclude the three former Soviet republics in the Baltic region as well as Ukraine. However, Clinton could not promise these

${ }^{258}$ Clinton, 569.

259 Ibid.

260 Ibid.

261 Thomas W. Lippman "Clinton, Yeltsin Agree on Arms Cuts and NATO," Washington Post, The Washington Post 22 Mar. 1997. http://www.washingtonpost.com/wp-srv/inatl/longterm/summit/summit.htm ${ }^{262}$ Clinton, 750. 
things and once again had to make clear that NATO was not interested in creating a barrier against Russia, but simply in the security and stability of the new democracies. One crucial element that helped sell the PFP and later NATO enlargement was that while new members would be covered by the Alliance's "nuclear umbrella," there would in fact be no new nuclear weapons within the $\mathrm{V} 3$ countries. Also the V3 member states would not receive new troops stationed within their countries. ${ }^{263}$ Eventually Clinton was able to get Yeltsin to agree to the NATO expansion as well as a NATO-Russia agreement in exchange for the US promising to not station troops and missiles in the new NATO member states. ${ }^{264}$ But it wasn't just Clinton and his administration that brought the $\mathrm{V} 3$ countries into NATO; it is imperative to remember that their role in the Yugoslav wars throughout the 90's played a significant part.

\section{The Yugoslav Wars}

Although Yugoslavia's civil and border wars began in 1991, the V3 Countries wouldn't become engaged until around 1993. As mentioned, the reason the Yugoslav wars are an important factor for the three Visegrad countries who wanted to join NATO is that it gave them the opportunity to show how serious they were about not only joining the military organization but also the Atlantic world. Kenney shows us that the Yugoslav wars "transformed the relationship between the whole of Eastern Europe and the West from one of dependence to one more symbiotic." ${ }^{265}$ At the same time the wars, and central

${ }^{263}$ Asmus, Opening NATO's Doors, 103.

${ }^{264}$ Clinton, 750.

${ }^{265}$ Kenney, Burdens of Freedom, 144. 
Europe's involvement, also showed the US as well as Western Europe how much European security rested on deeper cooperation. With regards to their involvement with the Yugoslav Wars, both Poland and the Czech Republic contributed to peacekeeping forces that were used in both the Croatian and Bosnian Wars. ${ }^{266}$ Of the initial 60,000 NATO troops deployed in 1996 to Bosnia, $1 / 6^{\text {th }}$ of those soldiers were from PFP engaged countries. ${ }^{267}$ Hungary specifically would play somewhat of a more important role during the Yugoslav wars, as it was the only country that bordered the country. By 1995, the US and NATO wanted southern Hungary to be the staging ground for the deployment of US and NATO-led forces into Bosnia. ${ }^{268}$ The Taszar military airbase located in southern Hungary would be NATO's access point into Yugoslavia and would be used to run bombing raids to help calm the crisis. ${ }^{269}$ Actions such as these helped show the US, NATO, and Western Europe that the above mentioned Visegrad countries could be counted on as allies in times of crisis. This would prove even more true in 2003 when the V4 countries became part of what was called the "coalition of the willing," which was a composed list of countries who supported then US President George W. Bush's invasion of Iraq. ${ }^{270}$ The importance of the coalition of the willing would be to show that the invasion of Iraq was legitimate and not just supported by the United States. Major countries including Germany

266 Ibid.

267 Asmus, Opening NATO's Doors, 125.

268 Asmus, Opening NATO's Doors, 128.

269 Ibid.

270 Steve Schifferes, "US Names 'Coalition of the Willing," BBC News, 18, March 2003. http://news.bbc.co.uk/2/hi/americas/2862343.stm. 
and France were against the invasion so it was important for the US to look for supporters so that they wouldn't look like a war mongering nation in the international community. ${ }^{271}$ Poland in particular would play the biggest role in the V4 as they, along with the United Kingdom and Australia, would contribute the highest number of invasion troops. ${ }^{272}$ It becomes clear that the V4 weren't just an important ally during the Yugoslav wars but also future conflicts to come.

\section{Transitioning into NATO}

Before entering NATO all three of the Visegrad candidates had to show that they had met certain NATO qualifications in order to be even considered possible candidates. In Opening NATO's Doors, Ronald Asmus shows us that the two main entities that would judge their qualifications were both NATO as a whole and the U.S. as its leading member. It is important to understand that unlike the EU, NATO has less specific criteria in order to become a member which means candidates tend to have more flexibility when applying for membership. With regards to NATO, the military alliance is concerned with two factors, performance of a country and strategic interest. ${ }^{273}$ Because of this ambiguity, the US would help aid the V3 by giving them their own set of criteria in order to help map out what exactly the $\mathrm{V} 3$ countries must do to gain membership in NATO. Named after US Secretary of Defense Bill Berry, the US issued the "Berry Principles" which were meant to serve as a guiding list of criteria that the

${ }^{271}$ Ibid.

272 Ibid.

${ }^{273}$ Asmus, Opening NATO's Doors, 148. 
V3 countries needed to complete in order to have the US's permission to join. The Principles included having a stable and fair democracy, a free market economy, civilian control of the military, settled borders, a resolution to minority and racial issues, and the compatibility of a nation's armed forces with NATO. ${ }^{274}$ All three of the candidates had trouble meeting at least one of the principles mentioned.

\section{The Czech Republic}

Two issues the Czech Republic had to face in order to be considered for membership into NATO included mending its relationship with two minority groups. First, the Czechs needed to "mend their fences with the Germans over the issue of expatriated Germans from the Sudetenland following WW II."275 President Havel quickly took care of this problem by creating better relations and issuing an official apology to Germany for the expulsion of Germans, in order to show how important NATO acceptance was to both him and his country. ${ }^{276}$

The second issue facing the Czech Republic was dealing with the Moravian region of the country as its population called for its own autonomy after the Velvet Divorce. In the Czech Republic, after the split, a movement in Moravia occurred that called for more power and autonomy to the Moravian people. The Moravians at the time thought that the Prague government was overextending its rule, so this Czech-speaking regional minority called for more local power and

274 Ibid, 147.

275 Ibid, 148.

276 Peter Green, "A Czech Seeks to Atone For a Nations Revenge," The New York Times, December 22, 2002. 
even a separate army. ${ }^{277}$ They were even prepared to establish their own state, which would be called the "Czech Lands". ${ }^{278}$ Both Havel and Klaus refused to take the Moravians seriously and they had a negative view of any further divisions within the country. Instead Havel and Klaus made agreements with the region in the mid 1990's to allow more of a role in "regulating policy in the social areas, notably education, health care, and social agreements" ${ }^{279}$ With these two issues handled the only thing left for the Czech Republic to take care of was restructuring and reforming it's military which was a necessity for all three of the NATO candidates. ${ }^{280}$ To accomplish this all three of the Visegrad countries would partake in drills and exercises over time in order to show that they were prepared in case a crisis were to ever break out.

\section{Hungary}

Just like the Czech Republic, Hungary also had to deal with minority issues that stemmed back to 1920 when the Treaty of Trianon was signed ending Hungary's involvement with WW I. After the treaty was signed 2 million Hungarians became national minorities in neighboring states. ${ }^{281}$ Specifically, Hungary had to reach agreements with Slovakia and Romania on border issues in order for its candidacy to NATO to be considered. With this in mind in March of 1995 Hungary reached an agreement with Slovakia in regard to minority rights in each country. Then in the fall of 1996, Hungary and Romania were able to reach

${ }^{277}$ Goldman, Revolution and Change, 149.

278 Ibid.

279 Ibid, 150.

${ }^{280}$ Asmus, Opening NATO's Doors, 148.

281 Ibid. 
a settlement that would also call for the respect of minority rights. ${ }^{282}$ Finally attention can be turned to the last Visegrad country Poland had the most difficult time meeting the criteria set out in the Berry Principles.

\section{Poland}

The two problems inhibiting Poland from being accepted into NATO included a lack of effective control of the military by civilians, and an upsurge in anti-Semitism after the fall of communism. During his presidency, Lech Wałęsa saw himself as the people's leader, meaning that all things that fell under the jurisdiction of the sate, including the military, were under his influence as the people had freely chosen him to represent them. ${ }^{283}$ With this in mind Walesa would build strong personal ties with leading military personnel who reported directly to him and did as he asked. This would in turn undercut the Ministry of Defense's ability to lead the military effectively. This issue would not be solved until 1996 when the newly elected Polish President, Alexsandr Kwasniewski signed new legislation that gave power over the military back to the Minister of Defense and out of the executive branch. ${ }^{284}$

With regard to Poland's second problem, anti-Semitism, after the fall of communism both the Government as well as Catholic Church failed to step in and denounce and punish anti-Semitic rhetoric behavior. To this day antiSemitism in post communist Poland remains an important issue as many still have negative attitudes toward the Jewish people. At the time, in 1991, 1/3 of

282 lbid.
283 lbid, 151.
284 lbid, 152. 
Poles thought that Jewish influence was too great in Poland, even though there were only 3,000 Jews living in Poland at the time ${ }^{285}$ As an overwhelming majority of the country is Catholic, one might think that the Catholic Church would stand firmly against such senseless hatred toward an already decimated population. Instead the opposite happened. In August of 1989, the head of the Polish Church Cardinal Jozef Glemp went on record saying that the Jewish people had been attacking Poles and Christians with the use of "Jewishcontrolled" media. ${ }^{286}$ Additionally, in June of 1995, the well-known priest Henryk Jankowski called for the removal of Jews from the government. Jankowski would go onto to claim that the Star of David, a treasured icon of the Jewish faith, was nothing more than an oppressive symbol, much like the swastika or hammer and sickle. ${ }^{287}$ What was most troublesome about this was that at the time, President Lech Wałęsa did not speak out against these anti-Semitic remarks; evidently the Polish president was simply not concerned about this issue. In the US, both Wałęsa and the government's response to these hateful actions outraged many American Jews. In particular the American Jewish Community demanded that before President Clinton allow Poland to join NATO it must first deal with AntiSemitism within the country. ${ }^{288}$ To smooth relations, Polish Ambassador to the US Jerzy Kozminksi worked night and day for three years to improve the relationship between Poland and the American Jewish community. It also helped that when President Kwasniewski came to power the Polish government was

${ }^{285}$ Goldman, Revolution and Change, 249.

${ }^{286}$ Ibid.

${ }^{287}$ Ibid.

${ }^{288}$ Asmus, Opening NATO's Doors, 148. 
more sympathetic to the Jewish population and would criticize those who made Anti-Semitic comments. ${ }^{289}$ Eventually these actions led to the American Jewish Community to support and endorse Poland's candidacy for NATO membership.

By 1997, Poland, Hungary, and the Czech Republic had shown they were capable of integrating into NATO with little difficulty and would receive invitations to join the military organization at the NATO summit in Madrid, Spain. ${ }^{290}$ In the spring of 1998, the US Senate voted 80-19 in favor of allowing Poland, Hungary, and the Czech Republic into NATO ${ }^{291}$ Finally in 1999 , NATO had fully admitted these countries as they had met the requirements laid out by the PFP and the Berry Principles as well as for their supporting roles during the Yugoslav wars. Upon hearing the news that Poland, Hungary, and the Czech Republic had been accepted into NATO, Clinton made a quick speaking tour throughout Central and Eastern Europe and was met everywhere with chants of "USA! USA!"292

\section{Conclusion}

Displayed above was an in-depth look at the policies implemented by the US in order to bring the V4 countries, minus Slovakia, into the European and Atlantic communities. As seen in Chapter 3 Slovakia had a more difficult time during its transition period and was not able to reap the benefits that were provided by the U.S. to the other three Visegrad countries. Through a specified foreign policy built on first getting these new democracies stabilized and secured,

289 lbid, 152.

290 Kenney, Burdens of Freedom, 147.

291 William C. Berman, From the Center to the Edge: The Politics and Policies of the Clinton Presidency (Lanham: Rowman \& Littlefield, 2001), 84.

292 Clinton, 750. 
the US hoped to support both economic and political freedom in this part of the world for the first time in decades. With the help of Secretary Albright and General Shalikashvili, the Clinton Administration was able to bring three of the V4 countries under the protection of NATO. Both Albright and Shalikashvili had personal reasons to want this project to succeed, and Clinton was insightful enough to capitalize on their passion for the people of this region. By placing former citizens of Central Europe in positions of leadership in his administration, Clinton was able to show that as a melting pot of cultures itself, the US was deeply committed to and invested in the future of this region and the proliferation of democratic ideals around the world. However it is imperative to be aware of the unprecedented opportunity the US had in expanding NATO which in turn expanded its influence both politically and militarily. The US cemented itself as the strongest world military force. That being said, the process had its barriers; then Russian President, Boris Yeltsin, had been squarely against the idea of NATO expansion because he saw the move as coming at the expense of Russia. However, with subtle tactics and diplomacy, Clinton was able to convince his Russian counterpart that NATO was the right answer for the former Warsaw Pact states, as well as for Russia. Also discussed was how the three countries were able to use the Yugoslav wars as a way to demonstrate their military reliability, which further helped them become accepted into NATO. This military reliability would again be demonstrated when George W. Bush formed the coalition of the willing in order to carry out the 2003 Invasion of Iraq. With this understanding of the Clinton-era policies that helped forge this new relationship, the last chapter 
will end by discussing the results of these efforts, to better understand how each country capitalized on its acceptance into the Atlantic world. 


\section{Ch. 4: Results and Conclusion}

\section{Foreign Investments and the EU}

Once accepted in NATO, Poland, Hungary and the Czech Republic saw an increase in foreign investments that led to an expansion of their economies. Slovakia, while not originally accepted by NATO in 1999, would also see a rise in foreign investment, which would eventually help its government plead Slovakia's case for acceptance into NATO ${ }^{293}$ With regards to the EU, the process of acceptance for Poland, Hungary and the Czech Republic began back in July of 1997 when the European Commission, the administrative body for the EU, entered negotiations with these countries for future membership. ${ }^{294}$ However, it should be noted that while negotiations had begun, there was still no guarantee that these countries would enter the EU any time soon. This is because the process for gaining entrance into the EU required extended negotiations and discussions on 30 separate chapters of accession criteria that ranged from topics such as agriculture to military policy. ${ }^{295}$ However, being in NATO had greatly helped Poland, Hungary and the Czech Republic as many of the requirements for the EU, such as military policy, were already established. By 2004, all of the V4 countries was deemed fit to join in what has been called the "Big Bang" expansion.

293 "Countries," EUROPA, European Union, http://europa.eu/abouteu/countries/index_en.htm.

${ }^{294}$ Kenney, Carnival of Revolution, 150.

${ }^{295}$ Ibid, 151. 
With regards to foreign investment, Hungary was able to grow its industries in mining, metallurgy, construction material, textiles and pharmaceuticals. ${ }^{296}$ Between 1999 and 2007, Hungary saw a steady growth of national GDP and a fall of inflation that greatly benefitted the country after years of recession. However, Hungary was hit hard by the '07/'08 financial crisis and only now is beginning to recover from it. Nevertheless, with a 3.2\% GDP increase in 2014 , things are starting to look better for Hungary. ${ }^{297}$ It is important note that because of these hard times, the current ruling party, FIDESZ, has begun to turn away from its western neighbors in hopes of striking more business deals with Russia. ${ }^{298}$ Viktor Orban and his conservative colleagues have upset relations with the other V4 nations as well, as all four members seem to have mixed opinions on how relations with Russia should be handled, an issue that will be discussed in more depth. At the same time, they appear to be united in their approaches to the refugee crisis.

The Czech Republic is considered one of the most developed and industrialized economies within Central Europe. After 1999, foreign and domestic investment in heavy/general machine building, iron and steel production, and the chemical industry helped usher in a period of steady economic growth. ${ }^{299}$ It is

296 "Hungary Data," The World Bank, The World Bank Group, 31 May 2015, http://data.worldbank.org/country/hungary.

297 Ibid.

${ }^{298}$ Casey Michel, "Hungary's Viktor Orban Walks in Putin's Footsteps," The Moscow Times, Moscow Times, 5 Aug. 2014. http://www.themoscowtimes.com/opinion/article/hungarys-viktor-orban-walks-inputins-footsteps/504632.html.

299 "Czech Republic Data," The World Ban, The World Bank Group, 31 May 2015. http://data.worldbank.org/country/czech-republic. 
interesting to point out that the Czech Republic was one of the few countries in Europe that was not profoundly affected by the ' $07 /$ '08 financial crisis due to its stable banking system which is considered much more cautious in terms of lending than in many of its EU counterparts. 2014 even saw a GDP increase of $2 \%$ with a $2.7 \%$ growth prediction for $2015 .^{300}$

Poland, which has become the largest economy in Central Europe and the $6^{\text {th }}$ largest in the EU, also saw steady economic growth throughout the early 2000's. Its major industries include energy production, steel, and agriculture, which currently employs $12.7 \%$ of the workforce in Poland. ${ }^{301}$ The average yearly growth rate during the early to mid-2000's was around 6\%; however, growth began to decline in 2007 as a result of the global financial crisis, even if Poland's economy never fell into recession. ${ }^{302}$ Nevertheless, in 2014, Poland's annual GDP growth was $3.2 \%$ and is currently staying steady. ${ }^{303}$

Finally attention can be turned to the last and currently fastest growing economy of the Visegrad group, Slovakia. From 2001 to 2007, the country saw the highest sustained GDP growth in the entire EU, reaching $10.7 \%$ in $2007 .^{304}$ Slovaks could attribute its economic growth to the success of the service sector and automobile production, specifically Volkswagen, Peugeot, and KIA Motors. ${ }^{305}$ However, just as many countries around the world, Slovakia was also affected by

300 Ibid.

301 "Poland Data," The World Bank, The World Bank Group, 31 May 2015. http://data.worldbank.org/country/poland.

302 Ibid.

303 Ibid.

304 "Slovak Republic Data," The World Bank, The World Bank Group, 31 May 2015. http://data.worldbank.org/country/slovak-republic\#cp_wdi/countries. 305 Ibid. 
the financial crisis of 2008 with a falling of economic growth and an increase in unemployment, currently at $12.1 \%{ }^{306}$ Finally Slovakia, unlike the other V4 countries, is also a member of the Eurozone.

With all of this economic success in the early 2000's, the way the Visegrad countries interacted with one another and with outside partners such as the US and EU changed drastically. Once all of the V4 countries were brought into NATO and the EU, relations with the US started to decline as US foreign policy shifted its attention toward the Middle East. This was also a time period when the V4 turned inward in order to focus on their emerging economies. While still in existence today, the V4 and Atlanticism as a whole has changed its main focus from a political/economic relationship to a more military-focused one.

\section{Visegrad Refocused}

In November of 2014, the Visegrad Youth Forum met in Banská Bystrica, Slovakia to discuss the current challenges and future of the V4. In reading about the forum, it is evident that the overwhelming concern of young people is a need to restructure the overarching approaches of the $\mathrm{V} 4$ countries to several different key issues. These issues primarily center around the V4's stance on the 2014 Ukrainian Crisis, and the V4's policies on energy security and independence..$^{307}$

With regard to the 2014 Ukrainian crisis, it is evident that both Hungary and the Czech Republic do not view the Russian invasion of Crimea as a

306 "Unemployment Rate by Sex and Age Groups' Monthly Average," EuroStat: Your Key to European Statistics, European Commission, 08 May 2015. http://ec.europa.eu/eurostat/en/web/products-datasets/-/UNE_RT_M. ${ }^{307}$ Ratislav Kacmar, "The Visegrad Youth Forum 2014: What do Students Fear About the V4," Visegrad Insight, Res Publica Foundation, 9 Feb. 2015. http://visegradinsight.eu/the-visegrad-youth-forum-201419022015/. 
credible threat to their security. ${ }^{308}$ As mentioned above, both Viktor Orbán and FIDESZ are turning more and more to Russia for trade, topped by gas imports, but on top of this, some politicians in the Czech Republic even view Russia as a "reliable ally."309 2014 was, in many ways, a year of confusion for the nations of the $\mathrm{V} 4$, as each had significantly different reactions to the events happening in Ukraine. Michal Koran, the Deputy Director of the Institute for International Relations in Prague, stated, "In 2014, we have all witnessed a sudden major dip in the Visegrad cooperation at political and strategic levels." ${ }^{310}$ With this in mind, many seem to hope that 2015 will be seen as a "do over" year in order to come to a consensus over how the V4 will proceed in dealing with Russia. ${ }^{311}$ For young people, the answer for the V4 will lie in regional cooperation, as all four of these countries are not as strong in the area of foreign policy when negotiating by themselves. Essentially, for young people, the most important agenda item the V4 needs to accomplish in 2015 is a common policy on how to deal with Russian aggression so that the $\mathrm{V} 4$ can once again present a united stance to the world on this very important issue.

As with many countries, another major area of concern for the future of the V4 is energy security and independence. At the beginning of this thesis, I mentioned that a significant problem in Europe today is its dependence on

308 Jakub Kufack, "Czech Security Policy and the Ukraine Crisis," Visegrad Insight, Res Publica Foundation, 2 Mar. 2015, http://visegradinsight.eu/czechsecurity-policy-and-the-ukraine-crisis03032015/.

${ }^{309}$ Ibid.

${ }^{310}$ Michal Koran, "What will 2015 Hold for Central Europe," Visegrad Insight, Res Publica Foundation, 5 Feb. 2015, http://visegradinsight.eu/what-will-2015-holdfor-central-europe05022015/.

311 Ibid. 
Russian oil and energy. Because of this dependency, many countries are unable to stand up to Russia in instances such as the crisis in Ukraine. With the events of March of 2014 heavily on their minds, one of the major concerns of young people is that the $\mathrm{V} 4$, especially Hungary and Slovakia, are far too dependent on Russian energy. ${ }^{312}$ Youth all across the V4 countries are calling for investments in new and sustainable sources of energy in order to promote energy security and independence. They believe that only through working together will the V4 countries have the strength and ability to establish energy security for the future. ${ }^{313}$

However, this is not to say that the V4 is at complete odds with one another on every issue. From Olaf Osica, Director of the Centre for Eastern Studies in Warsaw, it is clear that while there are new factors of tension among the member states there are still common interests such as the EU budget and environmental issues that will always need to be dealt with in some competitive manner. ${ }^{314}$ Another common factor is the V4's continued support of NATO positions, even if it sometimes conflicts with their individual stances. ${ }^{315}$ This may have to do with the fact that some believe that "without NATO the region ceases

312 Tomas Strazay, "Slovakia's Presidency of the V4: The Importance of the V4 will not decline," Visegrad Insight, Res Publica Foundation, 2 July. 2014.

http://visegradinsight.eu/slovakias-presidency-of-the-v4/.

${ }^{313}$ Kacmar, "The Visegrad Youth Forum 2014".

${ }^{314}$ Wojiech Przybylski, "A World is over: Prospects for cooperation between the counties of Central Europe," Visegrad Insight, Res Publica Foundation, 18 Dec. 2014. http://visegradinsight.eu/a-world-is-over18122014/.

${ }^{315}$ Przybylski, "Visegrad Differences will always exist: But the V4 is Much Stronger Than Critics Make Out". 
to exist as a whole in the dimension of security and defense." ${ }^{316}$ Conflicts over policy have always existed in Visegrad, however their common interests and ability to work as a united front have always been one of the keys to their success. Currently the V4 is entering a "new model" which will be built not on a level of ideas but rather built on normal political debate. ${ }^{317}$ It will be imperative that the V4 try and improve their organization by taking several steps. These steps would include increasing national contributions to the International Visegrad Fund, the only permanent institution of the V4 that was established in the year 2000, continuing to push for equality for women and minorities, respecting different financial powers within each member state, and focusing on a the Eastern partnership. ${ }^{318}$ Another area of cooperation that has recently come to the forefront is how the V4 are working together in the development of the 2015 Syrian Refugee Crisis, however it is not necessarily in the most positive light. Currently the V4 are completely against "any proposal leading to the introduction of mandatory and permanent quotas as solidarity measure would be unacceptable." 319 The V4 are going against the wants of both the European Commission and major countries like France as Germany as well as the Obama Administration who believe that the relocation of asylum seekers should occur in a timely manner. ${ }^{320}$ However, this is not to say that the V4 aren't taking any

\footnotetext{
${ }^{316}$ Przybylski, "A World is over."

317 Ibid.

318 Przybylski, "Visegrad Differences will always exist".

319 Eric Maurice, "Refugee Quotas 'Unacceptable' for Visegrad States," EUObserver, ASBL, 05, September 2015. https://euobserver.com/migration/130122. ${ }^{320}$ Ibid.
} 
measure to deal with the crisis, rather they believe that the right path is to take on the root causes of the Refugee crisis. Currently all four countries are engaged with setting up safe camps for newly arrived refugees in order to give them somewhere to stay whilst applying for asylum. ${ }^{321}$ They believe that actions including working to find a solution to the civil war in Syria and confronting the terrorist organization ISIS more forcefully will solve the root causes of the crisis. ${ }^{322}$ What this stance shows, though while not necessarily the most positive, is that while many differences may exist, the $\mathrm{V} 4$ isn't going anywhere anytime soon. From Tomas Strazay, head of the Central and Southeastern Europe Research Program in Bratislava, it is clear that V4 "cooperation is so multidimensional and well built that it's not possible to just end it." ${ }^{323}$

\section{Redefining Atlanticism}

Finally, the last major problem facing the V4 today is the issue of military cooperation and its role in the future of Atlanticism. Richard Sakwa, a professor of Russian and European Politics, notes that a new form of Atlanticism has developed since the mid-2000's. ${ }^{324}$ Atlanticism, which at first was just based on strengthening the economic, political, and military relations between Europe and North America, has devolved into a focus simply on military relations, which is evident in the relationship that has developed between the EU and NATO with

${ }^{321}$ Bill Ravotti. "The V4 Nations are Dealing with the Syrian Refugee Crisis Properly," Trib Live, Trib Total Media Inc. 19 Sep. 2015. http://triblive.com/opinion/featuredcommentary/9089147-74/refugees-countrieseurope\#axzz3q53V42wU

322 Ibid.

${ }^{323}$ Strazay, "Slovakia's Presidency of the V4".

${ }^{324}$ Richard Sakwa, "The New Atlanticism," Valdai Papers 17 (May 2015): 2. 
regard to security policies. For example, it has become clear that, for better or worse, the "foreign and security dimensions of the EU has effectively merged with the Atlantic security community." ${ }^{325}$ In simpler terms this means that in order for possible future members to join the EU, they will now have to align their security policies with those of NATO ${ }^{326}$

The problem with the militarization of Atlanticism is that new tensions with Russia are emerging that could easily slip the world back into a Cold War confrontation. ${ }^{327}$ While NATO and the US might have a positive view of the expansion of this new form of Atlanticism, what it really does is undermine panEuropean security. Because the EU and NATO are edging closer to Russia's borders, the Russian Federation feels pressured to defend what remains of its sphere of influence, the 2014 crisis in Ukraine being the most obvious example of this. Additionally, neither the US nor the EU has seemed to be able to let go of Cold War Era attitudes towards the actions of Russia, which are constantly questioned, or condemned. ${ }^{328}$ Sakwa states, "Any concession, or even understanding of the Russian position is considered weakness." ${ }^{329}$ In order to avoid mounting tensions, the EU, US, and V4 countries are going to need to move away from this new form of Atlanticism, which is too heavily focused on the military alliance, and come back to policies built on political and economic cooperation. In light of the events in the Crimea and Ukraine, it will be important

${ }^{325}$ Ibid, 6.

${ }^{326}$ Ibid.

327 lbid.

$328 \mathrm{lbid}$.

329 Ibid. 
to take note of Russian interests in its "near abroad" of former Soviet states, particularly those with large Russian minorities; otherwise, the Atlantic community might find itself in the midst of another cold war which benefits neither side.

\section{Conclusion}

Four countries in Central Europe were able to rise from the ashes of communist rule and become politically democratic countries with free market economies. It was shown saw that the reason the V4 countries wanted to "return to Europe" was because of their long historical and cultural ties that stem back to the medieval period. Security from a possible Soviet Union revival also drove the V4 to look for help from western countries. With regards to the main characteristics of post-communist policies that helped the V4 integrate into western institutions, the V4 countries underwent a transformation period to prove that they were ready to become democratically stable countries. From examining their transition process it is clear that the Visegrad countries had difficulties during this period, including rising unemployment and inflation that had never been experienced before. Although Slovakia pursued gradual economic reform, which hampered economic development throughout the 90's, the countries of Poland, Hungary, and the Czech Republic were able to move rather quickly from a communist command system to a system based on free market capitalism. Once the Clinton Administration recognized the security vacuum in the region by the collapse of the Soviet Union, it decided to step in to help guide these newly 
independent countries into the Atlantic World. However, the relationship between the US and V4 countries during the 1990's is often downplayed due to the other world events that overshadowed these dealings. By pushing for their acceptance into NATO first, the US helped bring the V4 into western institutions which would help make western European countries see that the Visegrad group was ready to join the EU. Before doing this both the US, in the form of the Berry criteria, and NATO would set up criteria that the V4 had to meet in order to be accepted into the military organization. These included settling border, minority, military and political disputes that made the new state of Slovakia ineligible to join NATO with the rest of the $\mathrm{V} 4$ countries in 1999. One must also not forget the significance of the Yugoslav wars that helped the V4 countries prove themselves to be strategically sound allies to NATO and the US. The V4 countries would play a vital role in ending the ethnic cleansing and murderous violence that occurred in former Yugoslavia during the 1990's. However it can not be stressed enough that no matter their proclaimed motives, the Clinton administration saw the collapse of the Soviet Union as a way to make NATO and the US's military importance relevant again. This was an event that allowed for the US to show the world what it stood for, liberal internationalism, and what its role would be in the future to come. As discussed the US would call upon the V4 to once again take military action when former President George W. Bush formed the coalition of the willing in order to legitimize the 2003 invasion of Iraq.

With acceptance into NATO, Poland, Hungary and the Czech Republic were seen as legitimate Atlantic allies, which had set up politically free 
democracies and had established working free-market economies. Acceptance into NATO also brought a surge of foreign investments as other countries took note of the political and economic achievements that the Visegrad countries had accomplished. This success would eventually lead all of the V4 countries to being accepted into the EU, bringing their acceptance into the Atlantic world full circle. With this thesis, I have demonstrated that the relationship between the US and V4 played a major role in the development of these countries after the fall of communism in the early 1990's and with US aid the V4 was able to join western institutions. Today, we see that while the mission of Atlanticism has been reduced to military cooperation, the need for a more embracing Atlanticism that should include political and economic cooperation is still strong. With mounting issues, such as the 2014 crisis in Ukraine and the 2015 Syrian refugee crisis, we see that the world needs Atlanticism now more than ever. However, if Atlanticism is to continue in the future, then both the US and EU need to bring the focus back to promoting political and economic collaboration in the forms of solving these kind of crisis. We see that with regards to the Syrian refugee crisis the V4 is united and committed to solving the root causes of the problem but are at odds with the European Commission, France, Germany and the Obama Administration on how to handle relocating refugees. For now all we can hope is that the US and $\mathrm{V} 4$, and more generally the $\mathrm{EU}$, will engage with one another in order to deal with the 2015 Syrian refugee crisis in a peaceful and positive manner. 


\section{Bibliography}

\section{Primary Sources}

- "Countries." EUROPA. European Union. http://europa.eu/abouteu/countries/index_en.htm.

- "Country and Lending Groups." Country and Lending Groups. N.p., n.d. Web. 08 Apr. 2015. http://data.worldbank.org/about/country-and-lendinggroups\#High_income.

- "Sustaining Human Progress: Reducing Vulnerabilities and Building Resilience." Human Development Report 201426.1 (2014): n. pag. UNDP, 2014. Web. 8 Apr. 2015. http://hdr.undp.org/sites/default/files/hdr14-report-en-1.pdf.

- "What Is NATO?" NATO. NATO, (May, 23 2014), http://www.nato.int/natowelcome/index.html.

- "About CEFTA." Summit of the Prime Ministers of CEFTA Countries. CEFTA, 6 Nov. 2003. Web. http://www.cefta2003.gov.si/eng/cefta.

- "Accession Criteria (Copenhagen Criteria)." EUROPA. European Union. http://europa.eu/legislation_summaries/glossary/accession_criteria_copen hague en.htm\#

- "Aims, Objectives and Extent." Summit of the Prime Ministers of CEFTA Countries. CEFTA, 6 Nov. 2003. Web. http://www.cefta2003.gov.si/eng/cefta/aims.

- "Business in Eastern Europe" The Economist, Sep. 21, 1991: 18-19. 
- "Central European Free Trade Agreement - CEFTA 2006." Central European Free Trade Agreement. CEFTA. http://www.cefta.int.

- "Czech Republic Data." The World Bank. The World Bank Group. 31 May 2015. http://data.worldbank.org/country/czech-republic.

- "Historical Background." Summit of the Prime Ministers of CEFTA Countries. CEFTA, 6 Nov. 2003. Web. http://www.cefta2003.gov.si/eng/cefta/history.

- "Hungary Data." The World Bank. The World Bank Group. 31 May 2015. http://data.worldbank.org/country/hungary.

- "Poland Data." The World Bank. The World Bank Group. 31 May 2015. http://data.worldbank.org/country/poland.

- "Slovak Republic Data." The World Bank. The World Bank Group, 31 May 2015. http://data.worldbank.org/country/slovak-republic\#cp_wdi/countries.

- “Unemployment Rate by Sex and Age Groups' Monthly Average." EuroStat: Your Key to European Statistics. European Commission, 08 May 2015. http://ec.europa.eu/eurostat/en/web/products-datasets/IUNE_RT_M.

- Albirght, Madeleine. Madam Secretary: A Memoir. New York: Miramax, 2003.

- Albright, Madeline. The Role of the Press in Political Change: Czechoslovakia 1968. Chicago: Columbia University, 1976. 
- Ananicz, Andrzej. "From the Anti-Communist Underground to NATO and the EU." International Visegrad Fund. http://www.visegradgroup.eu/thevisegrad-book/ananicz-andrzej-from-the

- Baker, Peter and Lyman, Rick. "Obama, in Poland, Renews Commitment to Security." The New York Times, June 03, 2014. http://www.nytimes.com/2014/06/04/world/europe/obama-ineurope.html? $r=0$.

- Bilefsky, Dan and Jane Perlez. "Vaclav Havel, Former Czech President, Dies at 75." The New York Times.18 Dec. 2011. http://www.nytimes.com/2011/12/19/world/europe/vaclav-havel-dissidentplaywright-who-led-czechoslovakia-dead-at-75.html? $r=0$.

- Clinton, Bill. My Life. New York: Knopf, 2004.

- Dohmen, Frank. "Cold Turkey: How Germany Could End Russian Gas Dependency." Spiegel Online, 2014. http://www.spiegel.de/international/business/german-alternatives-torussian-gas-numerous-but-pricey-a-967682.html

- Engelberg, Stephen. "Her Year of Living Dangerously," The New York Times Magazine. September 12, 1993, 38.

- Kacmar, Ratislav. "The Visegrad Youth Forum 2014: What do Students Fear About the V4?" Visegrad Insight. Res Publica Foundation, 9 Feb. 2015. http://visegradinsight.eu/the-visegrad-youth-forum-201419022015/. 
- Kacmar, Ratislav. "The Visegrad Youth Forum 2014: What do Students Fear About the V4?" Visegrad Insight. Res Publica Foundation, 9 Feb. 2015. http://visegradinsight.eu/the-visegrad-youth-forum-201419022015/.

- Kaufman, Michael T. “Jacek Kuron, of Solidarity, Dies at 70.” The New York Times. 17 June 2004. http://www.nytimes.com/2004/06/18/us/jacekkuron-of-solidarity-dies-at-70.html.

- Kiss, Csaba G. "How did Visegrad Cooperation Begin?" Visegrad Insight (1) 2012: 16-17.

- Koran, Michal. "What will 2015 Hold for Central Europe?" Visegrad Insight. Res Publica Foundation, 5 Feb. 2015. http://visegradinsight.eu/what-will2015-hold-for-central-europe05022015/.

- Kufack, Jakub. "Czech Security Policy and the Ukraine Crisis." Visegrad Insight. Res Publica Foundation, 2 Mar. 2015. http://visegradinsight.eu/czech-security-policy-and-the-ukrainecrisis03032015/.

- Lippman, Thomas W. "Clinton, Yeltsin Agree on Arms Cuts and NATO." Washington Post. The Washington Post 22 Mar. 1997. http://www.washingtonpost.com/wp-srv/inat//longterm/summit/summit.htm

- Lopez, German. “This Map Shows Europe’s Dependence on Russian Gas." Vox. Vox Media, 25, July 2014. http://www.vox.com/2014/7/25/5936521/why-europe-wont-punish-russiain-one-map. 
- Maurice, Eric. "Refugee Quotas 'Unacceptable' for Visegrad States.”

EUObserver. ASBL, 05, September 2015.

https://euobserver.com/migration/130122.

- Michel, Casey. "Hungary's Viktor Orban Walks in Putin's Footsteps.” The

Moscow Times. Moscow Times, 5 Aug. 2014.

http://www.themoscowtimes.com/opinion/article/hungarys-viktor-orban-

walks-in-putins-footsteps/504632.html.

- Nad, Jaroslav, Istvan Gyarmati, Tomasz Szatkowski, Libor Frank. "Policy

Paper: Trans-Atlantic Security," Visegrad Security Cooperation (2010): 110.

- Novak, Tamas. "Macroeconomic Outlook and Challenges in the V4," International Visegrad Fund (2010). http://www.visegradgroup.eu/otherarticles/macroeconomic-outlook.

- Przybylski, Wojiech "Visegrad Time Line." Visegrad Insight (1) 2012: 1415.

- Przybylski, Wojiech. "A World is over: Prospects for cooperation between the counties of Central Europe." Visegrad Insight. Res Publica Foundation, 18 Dec. 2014. http://visegradinsight.eu/a-world-isover18122014/.

- Przybylski, Wojiech. “V4 Dead of Alive?” Visegrad Insight (1) 2012: 3.

- Przybylski, Wojiech. "Visegrad Differences will always exist: But the V4 is Much Stronger Than Critics Make Out". Visegrad Insight. Res Publica 
Foundation, 26 Sep. 2014. http://visegradinsight.eu/visegard-differenceswill-always-exist26092014/.

- Ravotti, Bill. "The V4 Nations are Dealing with the Syrian Refugee Crisis Properly." Trib Live. Trib Total Media Inc. 19 Sep. 2015. http://triblive.com/opinion/featuredcommentary/9089147-74/refugeescountries-europe\#axzz3q53V42wU.

- Sakwa, Richard. "The New Atlanticism." Valdai Papers 17 (May 2015): 19.

- Schifferes, Steve. "US Names 'Coalition of the Willing." BBC News. 18, March 2003. http://news.bbc.co.uk/2/hi/americas/2862343.stm.

- Simecka, Martin M. "After the Velvet Divorce: Observations of a Double Insider." Visegrad Insight (1) 2012: 51-54.

- Smolar, Alexsander. "Does the Visegrad Group make sense in Today's Europe?" Visegrad Insight (1) 2012: 10-11.

- Strazay, Tomas. "Slovakia's Presidency of the V4: The Importance of the V4 will not decline." Visegrad Insight. Res Publica Foundation, 2 July. 2014. http://visegradinsight.eu/slovakias-presidency-of-the-v4/.

- Terenzani, Michaela. "A common but contentious History." International Visegrad Fund (2010). http://www.visegradgroup.eu/the-visegradbook/ananicz-andrzej-from-the.

- The Visegrad Group: The Czech Republic, Hungary, Poland and Slovakia. "1999/2000 Czech Presidency: Annual Reports on the Activities of the Visegrad Group." International Visegrad Fund. 
http://www.visegradgroup.eu/documents/annual-reports/1999-2000-czech110412.

- The Visegrad Group: The Czech Republic, Hungary, Poland and Slovakia. "2000/2001 Polish Presidency: Krakow, 1 June 2001." International Visegrad Fund. http://www.visegradgroup.eu/documents/annualreports/2000-2001-polish-110412.

- The Visegrad Group: The Czech Republic, Hungary, Poland and Slovakia. "2002/2003 Slovak Presidency: Annual Report of the Slovak Presidency in the Visegrad Group." International Visegrad Fund.

http://www.visegradgroup.eu/documents/annual-reports/2002-2003slovak-110412.

- The Visegrad Group: The Czech Republic, Hungary, Poland and Slovakia. "2003/2004 Czech Presidency: Report on Activities of the Czech Presidency of the Visegrad Group." International Visegrad Fund. http://www.visegradgroup.eu/documents/annual-reports/2003-2004-czech110412.

- The Visegrad Group: The Czech Republic, Hungary, Poland and Slovakia. "2004/2005 Polish Presidency: Activity of the Polish Presidency of the Visegrad Group." International Visegrad Fund. http://www.visegradgroup.eu/documents/annual-reports/2004-2005-polish110412.

- The Visegrad Group: The Czech Republic, Hungary, Poland and Slovakia. "Annual Reports of the Visegrad Group's Presidencies." International 
Visegrad Fund. http://www.visegradgroup.eu/documents/annualreports/annual-reports-of-the.

- The Visegrad Group: The Czech Republic, Hungary, Poland and Slovakia. "Contents of Visegrad Cooperation 1999." International Visegrad Fund. http://www.visegradgroup.eu/cooperation/contents-of-visegrad-110412.

- The Visegrad Group: The Czech Republic, Hungary, Poland and Slovakia. "Presidency Programs." International Visegrad Fund.

http://www.visegradgroup.eu/documents/visegrad-declarations/visegraddeclaration-110412-2.

- The Visegrad Group: The Czech Republic, Hungary, Poland and Slovakia. "Visegrad Declaration 1991." International Visegrad Fund. http://www.visegradgroup.eu/documents/visegrad-declarations/visegraddeclaration-110412-2.

- Visegrad Group: The Czech Republic, Hungary, Poland and Slovakia. "History of the Visegrad Group." International Visegrad Fund. http://www.visegradgroup.eu/about/history.

- Visegrad Group: The Czech Republic, Hungary, Poland and Slovakia. "The Visegrad Group--A Central European Constellation." International Visegrad Fund. http://www.visegradgroup.eu/documents/Fessaysarticles/the-visegrad-book. 


\section{Secondary Sources}

- Ágh, Attila. "Transition to Democracy in Central Europe: A Comparative View." Journal of Public Policy 11 no. 02 (1990): 133-151.

- Antohi, Sorin, and Tismaneanu, Vladimir. Between Past and Future: The Revolutions of 1989 and Their Aftermath. New York: Central European University Press, 2000.

- Asmus, Roland D. Opening Nato's Doors: How The Alliance Remade Itself for a New Era. New York: Columbia University Press, 2002.

- Asmus, Ronald D., and Vondra, Alexandr. "The Origins of Atlanticism in Central and Eastern Europe." Cambridge Review of International Affairs 18 no. 2 (2005): 203-16.

- Babiuch, Jolanta. "Church and Society in Post-Communist Eastern Europe." The World Today 50, no. 11 (November 1994): 211-215.

- Bakke, Elisabeth. "Central and East European Party Systems since 1989." Central and Southeast European Politics since 1989 (2009): 64-90. https://books.google.de/books?id=oFXdiS25N78C\&pg=PA79\&dq=fidesz+ national+conservative \&hl=de\&ei=55XGTuj7FZDNswaJ6bDtBg\&sa=X\&oi= book_result\&ct=result $\# \mathrm{v}=$ onepage $\& \mathrm{q}=$ fidesz $\% 20$ national $\% 20$ conservative $\& \mathrm{f}=$ false

- Berman, William C. From the Center to the Edge: The Politics and Policies of the Clinton Presidency. Lanham: Rowman \& Littlefield, 2001.

- Bjork, James. "“The Use of Conditionality: Poland and the IMF." Eastern European Quarterly 29. no. 1 (Spring 1995): 89-120. 
- Blood, Thomas. Madam Secretary: A Biography of Madeline Albright. New York: St. Martin's, 1997.

- Copsey, Nathaniel. "Poland an Awkward Partner Redeemed," The Member States of the European Union, edited by Simon Bulmer and Christian Lequesne, 187-209. Oxford: Oxford University Press, 2013.

- Corrin, Chris. Magyar Women: Hungarian Women's Lives, 1960s-1990s. New York: St. Martin's, 1994.

- Dobbs, Michael. Madeleine Albright: A Twentieth-century Odyssey. New York: Henry Holt, 1999.

- Dunne, Tim. "'When the Shooting Starts': Atlanticism in British Security Strategy." International Affairs 80, no. 5 (2004): 893-909. http://www.chathamhouse.org/sites/default/files/public/International\%20Aff airs/Blanket\%20File\%20Import/inta_424.pdf.

- Ekiert, Grzegrorz. The State against Society: Political Crises and Their Aftermath in East Central Europe. Princeton, NJ: Princeton UP, 1996.

- Garton Ash, Timothy. The Magic Lantern: The Revolution of '89 Witnessed in Warsaw, Budapest, Berlin, and Prague. New York, NY: Random House, 1990.

- Gati, Charles. ZBIG: The Strategy and Statecraft of Zbigniew Brzezinski. Baltimore, MD: The Johns Hopkins UP, 2013.

- Goldfarb, Jeoffrey. After the Fall: The Pursuit of Democracy in Central Europe. New York: Basic Books, 1992. 
- Goldman, Minton F. Revolution and Change in Central and Eastern Europe: Political Economic, and Social Challenges. Armonk, NY: M.E. Sharpe, 1997.

- Goldman, Minton F. Slovakia since Independence: A Struggle for Democracy. Connecticut: Praeger Publishers, 1999.

- Green, Peter. "A Czech Seeks to Atone For a Nations Revenge." The New York Times. December 22, 2002.

- Hamilton, Nigel. Bill Clinton: An American Journey. New York: Random House, 2003.

- Hixson, Walter L. Parting the Curtain: Propaganda, Culture and the Cold War 1945-1961. New York: St. Martin's Griffin, 1998.

- Hopf, Ted. "The Promise of Constructivism in International Relations Theory." International Security 23.1 (1998): 171-200.

- Horak, Martin. "Governing The Post Communist City: Institutions and Democratic Development in Prague." Toronto: University Toronto Press, 2007.

- Hua, Xing. "EU Enlargement in the $21^{\text {st }}$ Century: New Stage and Challenges." CIIS.org. China Insitute of International Studies, 23 Sept. 2014. http://www.ciis.org.cn/english/2014-09/23/content_7254504.htm.

- Johnson, Lonnie R. Central Europe: Enemies. Neighbors, Friends. Oxford, ENG: Oxford UP, 1996.

- Kenney, Padraic. A Carnival of Revolution: Central Europe 1989. Princeton, NJ: Princeton UP, 2002. 
- Kenney, Padraic. The Burdens of Freedom: Eastern Europe since 1989. London, UK: Zed Books Ltd, 2006.

- Kirchner, Emil Joseph. Decentralization and Transition in the Visegrad: Poland, Hungary, the Czech Republic and Slovakia. New York: St. Martin's, 1999.

- Killingsworth, M. Klatt, M. and Auer, S. "Where does Poland fit in Europe? How Political Memory Influences Polish MEPs' Perception of Poland's Place in Europe." Perspectives on European Politics and Society. Vol. 11, No. 4 (2010): 358-375.

- Kovrig, Bennett. Of Walls and Bridges: The United States and Eastern Europe. New York: New York UP, 1991.

- Kurski, Jaroslav. Lech Walesa: Democrat or Dictator? Boulder, Co: Westview Press, 1993.

- LaFeber, Walter. The American Age: U.S. Foreign Policy at Home and Abroad since 1896. New York: Norton, 1994.

- Michta, Andrew. "The Presidential Parliamentary System." in The Transition to Democracy in Poland. ed. Starr: 69-70.

- Roberts, Adam. Civil Resistance in the East European and Soviet Revolutions. Cambridge, MA: Albert Einstein Institution, 1991.

- Richelle, Koos. "Adapting to the Change: The EU Approach to restructuring." Social Agenda. July 2011: 1-28.

- Sanford, George. Democratization in Poland, 1989-1990: Polish Voices. New York: St. Martin's Press, 1994.

- Strayer, Robert W. Why Did the Soviet Union Collapse?: Understanding 
Historical Change. Armonk, NY: M.E. Sharpe, 1998

- Stokes, Gale. The Walls Came Tumbling Down: The Collapse of Communism in Eastern Europe. Oxford, ENG: Oxford UP, 1993.

- Swiatowski Cannon, Lucja. "Privatization Strategy and Its Political Context," in The Transition to Democracy in Poland, ed. Starr: 122-141.

- Swieboda, Pawel. "In NATO's waiting room," Transistion 2, no. 8 (April 19, 1996): 52-55.

- Titkov, Anna. "Polish Women in Politics: An Introduction to the Status of Women in Poland," Women in the Politics of Postcommunist Eastern Europe, ed. Rueschemeyer: 29-34. 